\title{
THE ENGLISH WET-NURSE AND HER ROLE IN INFANT CARE 1538-1800
}

by

\section{VALERIE FILDES*}

Despite the space devoted to studies of European nurses, wet-nursing in England has received scant attention. This is mainly because in some countries, such as France, wet-nursing was regulated by the state and therefore was documented extensively. Also, France and most other Catholic lands had numerous foundling hospitals for which detailed records, often dating from the Middle Ages, survive. But for England, apart from the archive relating to the country nurses of the London Foundling Hospital (founded 1739), and the few remaining records of the nurses employed by Christ's Hospital in the sixteenth century, the evidence is limited and scattered. ${ }^{1}$ How the trade of wet-nursing was organized and carried on outside these official institutions has received very little attention. Roger Finlay's study of the demography of London (1580-1650) has demonstrated that infants from wealthier parishes were sent out of London to be nursed in country parishes. ${ }^{2}$ Dorothy McLaren's detailed study of the Buckinghamshire parish of Chesham (1578-1601) has indicated that women who were nursing London infants may have used wet-nursing as a contraceptive technique once

* Valerie A. Fildes, BSc, SRN, PhD, Holt View, Lye Hill, Breachwood Green, Hitchin, Herts.

This paper is the first of several about wet nursing in England written between 1983 and 1987. Due to different publishing schedules some later papers, which develop further some of the points touched on here, are already in print. See Valerie Fildes, Breasts, bottles and babies: $A$ history of infant feeding, Edinburgh University Press, 1986, especially chs. 5, 6, 7 and 11; Wet nursing. A history from earliest times to the present, Oxford, Basil Blackwell especially chs. 5, 6, 8, 11 and 12; 'The wet nursing of London's children 1538-1800', in W. F. Bynum (ed), Living and dying in London 1500-1900, London, Routledge (in press); 'The wet nurses of the London Foundling Hospital 1756-1767', to be published in Continuity and Change.

1 The best summary of the French wet-nursing system is George Sussman, Selling mothers' milk. The wet nursing business in France 1715-1914, Chicago and London, University of Illinois Press, 1982. Wet-nursing of foundlings is described in An account of the foundation and government of the Hospital for Foundlings in Paris, London, 1739; Regulation of the Hospital at Lisbon, [n.d.]; Richard C. Trexler, 'The foundlings of Florence 1395-1455', Hist. Childhood Quart., 1973, 1: 259-284; Richard Palmer, 'Foundlings in the Venetian Republic in the sixteenth century', Seminar at the Institute of Historical Research, 12 March 1984; Jonas Hanway, A candid historical account of the hospital for the reception of exposed and deserted young children, London, 1759; Ruth McClure, Coram's children. The London Foundling Hospital in the eighteenth century, New Haven, Conn., and London, Yale University Press, 1981; V. E. Lloyd Hart, John Wilkes and the Foundling Hospital at Aylesbury 1759-1768, Aylesbury, HM \& M, 1979; E. H. Pearce, Annals of Christ's Hospital, London, Hugh Reed, 1908; Carole Cunningham, 'Christ's Hospital; infant and child mortality in the sixteenth century', Local Population Studies, 1977, 18: 37-40.

2 Roger A. P. Finlay, Population and metropolis. The demography of London 1580-1650, Cambridge University Press, 1981. 
their own families were complete. ${ }^{3}$ The works of Shorter on the history of the family ${ }^{4}$ and De Mause on the history of childhood ${ }^{5}$ cite many examples of wet-nursing, but their tendency to extrapolate findings from several different countries and from different periods make these of little value to the study of the English situation. The primary sources for "unofficial" wet-nursing are generally biased towards the consumers: diaries and autobiographies from about 1500 to 1800 frequently describe individual cases of the use of wet-nurses, although these relate almost exclusively to the upper or professional classes. ${ }^{6}$ To date, very little has been published about who the nurses were, their working conditions, and the degree of care they provided: points relevant both to infant care and the lives of women in pre-industrial England.

In a previous study of infant feeding practices in the British Isles 1500-1800, ${ }^{7}$ wet-nursing was considered in relation to other aspects of infant nutrition, particularly the attitudes towards breast-feeding and the development of artificial feeding. It was argued: (1) that wet-nursing was common, especially in the London area, during the sixteenth and seventeenth centuries and possibly increased in the late seventeenth and early eighteenth centuries; (2) that the nurses were married women living with their husbands, had several children of their own, and took the nurse-children into their own homes; (3) that they came chiefly from the artisan class rather than the poorest rural classes; (4) that there were three different types of wet-nurse: (a) the parish nurse who took in parish infants and was usually receiving poor relief herself; (b) the nurses of the London Foundling Hospital who worked under the supervision of inspectors; (c) the privately employed nurse, for whom wet-nursing was a significant and continuing occupation for which she received a good wage both in money and in kind: often she was cared for by her nurse-children in later life and received the occasional bequest from them.

This paper is concerned principally with this last type of nurse. The method employed in the research and the main results will be given first; followed by a more detailed discussion of the findings.

The rare references to wet-nursing by modern writers indicate that it was less popular in the late eighteenth century, accompanying the fashion for maternal breast-feeding. Certainly, in literary sources the mention of wet-nurses declines quite sharply in the eighteenth century; and similarly, medical works, whether intended for a professional or

\footnotetext{
${ }^{3}$ Dorothy McLaren, 'Nature's contraceptive. Wet nursing and prolonged lactation: the case of Chesham, Buckinghamshire, 1578-1601', Med. Hist., 1979, 23: 426-441. A similar finding has been described for Italy in Sandra Cavallo, 'Strategie politiche e familiari intorno al baliatico. Il monopolio dei bambini abbandonati nel Canavese tra seie settecento', Quaderni Storici, 1983, 53: 391-420, 735-736.

${ }^{4}$ Edward Shorter, The making of the modern family, Glasgow, Fontana, 1977.

5 Lloyd De Mause, The history of childhood, London, Souvenir Press, 1976, particularly ch. 1: 'The evolution of childhood', pp. 1-73.

${ }^{6}$ Linda Pollok, Forgotten children: parent-child relations from 1500-1900, Cambridge University Press, 1983, pp. 212-222; Rosalind K. Marshall, 'Wet nursing in Scotland: 1500-1800', Review of Scottish Culture, 1984, no. 1, 43-51; Randolph Trumbach, The rise of the egalitarian family, New York, Academic Press, 1978, particularly ch. 5; Lawrence Stone, The family, sex and marriage in England, 1500-1800, London, Weidenfeld \& Nicolson, 1977, pp. 99-101, 106-107, 428-432. See also my book, Breast, bottles and babies. $A$ history of infant feeding, Edinburgh University Press, 1986, chs. 5-7.

7 Valerie Fildes, 'The history of infant feeding 1500-1800', unpublished PhD thesis, University of Surrey, 1982, pp. 149-162 (hereinafter Fildes, thesis). The present investigation represents an attempt to extend and verify or refute these findings, which were based upon medical, theological, literary, and pictorial sources.
} 


\section{Valerie Fildes}

for a popular readership, rarely refer to wet-nurses, instead either advocating the increasing fashion for bringing up by hand at home, or the mother breast-feeding at home. ${ }^{8}$ Discussion with historians studying the eighteenth century ${ }^{9}$ produced no facts or figures about the wet-nurse in that period, although it was suggested that the London Foundling Hospital, when looking for suitable wet-nurses, may have built upon existing links around London and put foundlings to nurse with women in those villages known to accept nurse-children. Enquiries at the record offices around London produced no evidence of detailed research into this topic during any period.

In order to discover exactly when and where infants were put out to nurse, who these children were, and to which families they were sent, a systematic study was begun of the parishes in one county near London known to have taken nurse-children from London and its environs. The results from this county were compared with a sample of parishes from different counties around London. The county selected for detailed attention was Hertfordshire, a large, predominantly rural county whose nearest point to London was twelve miles and the farthest point approximately forty miles away. The sample from other counties was taken from a selection of those parishes whose registers had been printed and were available for study in the British Library: Bedfordshire, Buckinghamshire, Middlesex, and Essex to the north of the Thames, and Kent and Surrey to the south.

There are 132 parishes in Hertfordshire and, to date, sixty-two of these have been studied, although not in equal depth; in some cases because only the Bishop's Transcripts were available for part or all of the period from 1538 to 1800 , in others because only small parts of the register had survived loss or serious damageparticularly by fire. Many of the registers had gaps in the burials especially during the period $c .1640$ to $c .1660$. However, for this study, perfect registers, although desirable, were not essential. The aim was to discover, by examination of the burial registers, whether or not nurse-children were listed and, if so, to assess what proportion of all burials in any particular year comprised nurse-children. Further details sought were the place of origin of the nurse-child, and the family to which his care and nourishment during infancy was entrusted. Apart from the bald description "A nurse child", entries which were accepted gave varying amounts of detail: "Alice Ward, a nurse child of London" (Flamstead, Herts, 1552); "Andrew Rich a nurse child from London out of Georges Thornes house" (Much Hadham, Herts, 1572); "Thomas sonne of Anthony Kymber of London butcher nursed by the wyfe of John Edwards turner" (Chesham, Bucks, 1597); "John Greene, a nurse child of John Tyrrells at the butts, the son of one John Greene, a cutler in St Brid's parish in London"' (Stoke D'Abernon, Surrey, 1625); "A nurslinge of Goodman Johnsons, of High Ongar" (Ongar, Essex, 1639); "John Churchhill, a nursery, from Richard Butts house, from Westminster" (Kensington, Middlesex, 1663); "Kirgates nurse child" (Wimbledon, Surrey, 1709); "I.R., a nurse-child" (Totteridge, Herts, 1779); "John Bedgate infant son of John B., servant, nursd at Putney" (Putney, Surrey, 1799). It appears to have been normal practice for infants to be buried in the wet-nurse's own parish and not returned to their parishes of origin.

8 Ibid. p. 213.

${ }^{9}$ I am grateful for the opinions of Dr Roy Porter and Dr Keith Snell. 
It must be emphasized that in every case where nurse-children appear in a parish, the number sent there is always an underestimate. Registers record only those children buried there. Also, where burial registers do not record nurse-children this does not necessarily mean that nurse-children were never sent there, merely that none had died and had its burial recorded in the parish. In some cases where very brief details were given by a particular clerk, there may have been burials of infants at nurse who were not identified as nurse-children. Some parishes buried nurse-children for a few years only, whilst burials in others spanned a period of 250 years. A further point is that Hertfordshire was well known for its large numbers of non-conformists, especially in the seventeenth century, ${ }^{10}$ and although the few surviving registers of religious dissenters show no evidence of nurse-children, it is uncertain whether nursed infants were buried according to the faith of the wet-nurse or that of their family.

Before stating the findings of this study so far, it must be emphasized that this is a preliminary report, at approximately the half-way stage in an extensive work, and further study may well alter the findings, and consequently the opinions, stated here. However, the facts discovered to date are strongly indicative of particular trends and may provide a starting-point for studies of female occupations and, especially, infant and child care in pre-industrial England.

Of the sixty-two Hertfordshire parishes studied thirty-six (fifty-eight per cent) accepted nurse-children, principally from London, and between 1544 and 1800 they buried 1,912 nurse-children. ${ }^{11}$ In addition, there were seven Hertfordshire parishes not yet studied in detail but known from other records to have accepted London nurse-children. ${ }^{12}$ Twenty-five parishes from counties other than Hertfordshire buried 1,148 nurse-children in the period $1541-1800{ }^{13}$ Figure 1 shows the parishes known to accept London nurse-children between 1538 and $1800 .{ }^{14}$ Because this study

\footnotetext{
${ }^{10}$ The standard work on this subject is William Urwick, Non-conformity in Hertfordshire, London, Hazell, Watson \& Viney, 1884.

${ }^{11}$ The Hertfordshire parishes studied are listed alphabetically (in the format used by the Hertfordshire Record Office, Hertford) at the end of this paper. All references in the text to a particular parish allude to the records listed unless an additional footnote is given. A large majority of these records are not paginated; therefore, where possible, the year or decade referred to is given in the text.

${ }_{12}$ Great Amwell, Broxbourne, Hertford All Saints, Hertford St Andrews, Hertingfordbury, Brent Pelham, Ware. William Le Hardy (editor), Calender to the sessions books and sessions minute books and other sessions records of the county of Hertford 1619 to 1657, vol. 5, Hertford, Charles Longmore, 1928, p. 378; idem, (editor), Calender to the sessions books and other sessions records 1658-1700, vol. 6, Hertford, Elton Longmore, 1930, pp. 106, 304, 399; E. W. Paddick, 'When Hoddesdon harboured London's children', Hertfordshire Countyside, 1973, 28(165): 37-39; Pearce, op. cit., note 1 above, p.163; part of a handwritten transcript of the parish register of Brent Pelham, HRO; personal communication from Dr Violet Rowe.

${ }_{13}$ The parishes studied are listed alphabetically, by county, at the end of this paper. Unless an additional footnote is provided, all references to these parishes in the text refer to those listed.

${ }_{14}$ In addition to the parishes described in notes 11-13 above: J. Charles Cox, The parish registers of England, London, Methuen, 1910, pp. 67-69 (Mitcham, Surrey); The Christ's Hospital Book, London, Hamish Hamilton, 1953, p. 12 (Dunmow and Thaxted, Essex); T. F. Thiselton-Dyer, Old English social life as told by the parish registers, London, Eliot Stock, 1898 (Mitcham, Petersham, and Limpsfield, Surrey); Gerald Curtis, The story of the Sampfords, 1982, p. 46 (Great and Little Sampford, Essex), I am grateful to Mr F. G. Emmison of the Essex Record Office for providing this reference. F. G. Emmison, Elizabethan life: morals and the church courts, Chelmsford, Essex County Council, 1973, p. 88 (Farnham, Essex); Robert Edmund Chester Waters, Parish registers in England. Their history and content, London, Longmans, Green, 1887, p. 66 (Hackney and Highgate, Middlesex; Petersham, Surrey); W. Winters, Our parish registers, being three hundred years of curious local history, as collected from the original registers, churchwardens accounts and monumental records of the parish of Waltham Holy Cross, Waltham Abbey, [the author], 1885, pp. 74, 82, 103
} 


\section{Valerie Fildes}

concentrated particularly on Hertfordshire, this figure shows a larger number of parishes from this county; there is no evidence to suggest that more nurse-children were buried in Hertfordshire than in other counties around London. The numbers of nurse-children buried in each parish varied greatly, and Table 1 shows the years within which nurse-children appear in the burial registers of the thirty-six parishes. Table 2 shows a similar picture for the twenty-five parishes outside Hertfordshire used for comparison.

\section{TABLE 1: THE YEARS WITHIN WHICH 36 HERTFORDSHIRE PARISHES BURIED 1,912 NURSE-CHILDREN 1544-1800"11}

Name of parish
Aldenham
Anstey
Chipping Barnet
Bengeo
Berkhamstead
Bishops Stortford
Cheshunt
Codicote
Elstree
Flamstead
Great Gaddeston
Little Hadham
Much Hadham
Harpenden
Hatfield
Great Hormead
Hunsdon
Kings Langley
North Mimms
Northaw
Northchurch
Rickmansworth
St Albans Abbey
St Albans, St Peter's
St Albans, St Stephen's
Sandridge
Sarrat
Shenley
Stevenage
Totteridge
Tring
Walkern
Watford
Watton-at-Stone
Wheathamstead
Wigginton

Records studied
between
$1559-1800$
$1540-1800$
$1563-1795$
$1606-1800$
$1606-1669$
$1561-1800$
$1559-1800$
$1558-1800$
$1585-1800$
$1548-1800$
$1558-1800$
$1559-1800$
$1559-1800$
$1562-1800$
$1604-1800$
$1538-1800$
$1546-1800$
$1558-1812$
$1604-1800$
$1564-1713$
$1606-1800$
$1569-1695$
$1558-1760$
$1558-1800$
$1561-1697$
$1559-1800$
$1581-1714$
$1604-1800$
$1543-1800$
$1569-1800$
$1606-1800$
$1558-1800$
$1539-1800$
$1609-1699$
$1604-1800$
$1601-1800$

Nurse-children
buried between
$1594-1726$
1692
$1590-1630$
1638
$1606-1636$
$1608-1695$
$1559-1767$
$1635-1749$
$1585-1742$
$1551-1622$
1561
$1616-1714$
$1567-1710$
$1575-1714$
$1661-1788$
$1582-1592$
$1594-1686$
$1594-1731$
$1614-1752$
$1665-1689$
1607
1600
$1600-1674$
$1566-1739$
1630
$1595-1703$
$1693-1697$
$1640-1767$
$1544-1546$
$1581-1799$
$1607-1610$
1668
$1544-1735$
$1610-1671$
$1630-1694$
1624

No. of
nurse-children
261
1
30
1
7
7
703
5
247
27
1
31
48
50
41
5
24
58
65
10
1
1
8
31
1
15
3
17
6
64
2
1
131
4
4
1

(Waltham Abbey, Essex); Frieda Houser, 'Hampstead through the stethoscope', unpublished lecture (Hampstead, Middlesex); Le Hardy (1928), op. cit., note 12 above, pp. 291, 329 (Much Munden and Standon, Herts); Le Hardy (1930), op. cit., note 12 above, pp. 160 (Essendon, Herts); T. R. Forbes, Chronicle from Aldgate. Life and death in Shakespeare's London, New Haven Conn., and London, Yale University Press, 1977, p. 195 (Hatfield Broad Oak, Essex), I am grateful to the late Dr D. McLaren for providing this reference. Roger A. P. Finlay, 'Population and fertility in London 1580-1650', J. Family History, 1979, 4: 
The English wet-nurse and her role in infant care 1538-1800

TABLE 2: THE YEARS WITHIN WHICH 25 PARISHES OUTSIDE HERTFORDSHIRE BURIED 1,148 NURSE-CHILDREN 1541-1800 ${ }^{13}$

\begin{tabular}{|c|c|c|c|}
\hline Name of parish & $\begin{array}{l}\text { Records studied } \\
\text { between }\end{array}$ & $\begin{array}{l}\text { Nurse-children } \\
\text { buried between }\end{array}$ & $\begin{array}{r}\text { No. of } \\
\text { nurse-child }\end{array}$ \\
\hline \multicolumn{4}{|l|}{ Bedfordshire } \\
\hline Barton-le-Clay & $1558-1800$ & $1674-1769$ & 5 \\
\hline Compton-cum-Shefford & $1572-1800$ & $1634-1703$ & 2 \\
\hline Dunstable & $1558-1800$ & $1642-1699$ & 2 \\
\hline Houghton Regis & $1538-1800$ & $1541-1586$ & 7 \\
\hline Luton & $1602-1754$ & 1658 & 1 \\
\hline Streatley & $1602-1800$ & 1759 & 1 \\
\hline Sundon & $1584-1800$ & 1606 & 1 \\
\hline Toddington & $1616-1800$ & $1616-1742$ & 4 \\
\hline \multicolumn{4}{|l|}{ Buckinghamshire } \\
\hline Chesham & $1538-1636$ & $1575-1635$ & 60 \\
\hline Stoke Poges & $1563-1653$ & $1606-1640$ & 13 \\
\hline \multicolumn{4}{|l|}{ Essex } \\
\hline Ongar & $1558-1750$ & 1639 & 2 \\
\hline Stapleford Tawney & $1558-1752$ & $1565-1567$ & 2 \\
\hline \multicolumn{4}{|l|}{ Kent } \\
\hline Lee & $1579-1754$ & $1583-1730$ & 8 \\
\hline Lewisham & $1558-1729$ & $1578-1729$ & 71 \\
\hline Orpington & $1560-1754$ & $1581-1715$ & 24 \\
\hline \multicolumn{4}{|l|}{ Middlesex } \\
\hline Kensington & $1539-1675$ & $1576-1674$ & 34 \\
\hline \multicolumn{4}{|l|}{ Surrey } \\
\hline Banstead & $1548-1789$ & $1557-1752$ & 6 \\
\hline Beddington & $1538-1672$ & $1579-1671$ & 9 \\
\hline Merstham & $1538-1800$ & $1561-1756$ & 3 \\
\hline Morden & $1634-1800$ & $1636-1745$ & 9 \\
\hline Stoke D'Abernon & $1619-1800$ & $1625-1655$ & 4 \\
\hline Sutton & $1636-1800$ & $1640-1641$ & 2 \\
\hline Putney & $1620-1800$ & $1620-1800$ & 494 \\
\hline Wandsworth & $1603-1787$ & $1603-1748$ & 248 \\
\hline Wimbledon & $1599-1800$ & $1606-1738$ & 136 \\
\hline
\end{tabular}

There is no doubt that a nurse-child was one who had been sent to the country to be wet-nursed, at least initially. Every parish register examined to date discriminates between parish-child; nurse-child; poor nurse-child; nurse-child or child from the hospital (i.e. Christ's Hospital in the sixteenth century and the Foundling Hospital in the eighteenth century). In all parishes, even where nurse-children are not recorded, large numbers of infants/children were buried, each of whom was described as the son

26-38; Finlay, op. cit., note 2 above, (Enfield and Edmonton, Middlesex; Richmond and Titsey, Surrey; Waltham Abbey, Essex); John Southerden Tate, The history of parish registers in England, reprint of 2nd ed., 1862, Wakefield, Yorks, EP Publishing, 1976, pp. 121, 126 (Eltham and Shorne, Kent); Margaret Sherren, 'Edward and Mary Clarke of Chipley', Studies in Somerset History, University of Bristol, Dept of Extra-Mural Studies, 1971, p. 50 (Ditton, Surrey); I am grateful to the late Dr D. McLaren for providing this reference. J. O. Halliwell (editor), The private diary of Dr John Dee, London, Camden Society, 1842, pp. 12, 19, 39 (Barnes, East Sheen, and Petersham, Surrey); Hugh Cholmley, The memoirs of Sir Hugh Cholmley, London, 1787, (Wateringbury, Kent); E. M. Symonds (editor), 'The diary of John Greene (1635-1657)', Eng. 
or daughter of a Londoner whose name and occupation was given (most commonly a merchant or gentleman) and frequently addressed as "Sir" or "Mr" at a time when these titles were reserved for comparatively few wealthy or respected men. These appear in such large numbers that it is probable that many of them represent young children who were no longer wet-nursed but had been weaned and remained as foster-children, either with their old nurses or in other families in a healthy country parish until considered sufficiently old and resilient to return to their parents. In this study, these children have not been counted as nurse-children but if, as some authors maintain, ${ }^{15}$ they should be included, then the total figure of 3,060 nurse-children would represent only a fraction of those London children buried in the counties round the capital. Only children designated specifically as a nurse-child, nursery, or said to be nursed by a parishioner were included for the purposes of this investigation. Occasionally, infants were buried who were called "a sucking child", and these also were not counted as nurse-children since they were probably being suckled by their mothers. No children who were breast-fed at home were referred to as nurse-children by parish clerks, but were called "sucking child" or "infant son/daughter of [usually] a local man". In contrast, the surnames of nurse-children rarely occur elsewhere in the register.

Because the term "nurse-child" was well known to all parish clerks and others who wrote in the registers, and was universally used throughout the period under investigation, it is unlikely to indicate children other than those brought from other parishes, especially those of London. Nurse-children from Christ's Hospital in the sixteenth century and the Foundling Hospital in the eighteenth century might occasionally indicate a child no longer being breast-fed, but even in these cases, parish clerks discriminated between "A foundling from the Hospital" (often with the child's name and hospital number appended) and "A nurse child, foundling from the hospital". Similarly, they referred to children from Christ's Hospital either as "A nurse child from the Hospital" or "A poor child from the Hospital". ${ }^{16}$ In many cases, differentiation was made between "a nurse child" and "A poor nurse child", indicating that the latter was possibly a foundling or other poor child from a London parish sent out by parish officials to a foster-mother until old enough to return. ${ }^{17}$

Examination of overseers' and churchwardens' reports shows that children being buried as nurse-children were not those which the parish itself was supporting. ${ }^{18}$ Further, the women who were nursing the parish poor were not the women who were burying infants described as nurse-children. If the children being nursed at the expense of the parish died, they were described in the burial register as "an infant kept by" or "son or daughter of a parishioner", or occasionally as "foundling" or "base born".

\footnotetext{
hist. Rev., 1929, 44: 106-117 (Shenfield, Essex); Sarah Meade, Letter to her mother, Margaret Fox, 17 April 1686, Abraham Manuscripts No. 30, Friends House Library, London (Romford, Essex); unpublished records of the Cambridge Group for the History of Population and Social Structure (Bromley and Eltham, Kent; Northolt, Middlesex).

${ }_{15}$ For example, Finlay op. cit., note 14 above included these when other entries naming nurse-children occurred.

${ }^{16}$ For example, Much Hadham, Herts in the 1570s, and Hatfield, Herts in 1757.

${ }^{17}$ For example, Cheshunt, Herts, in 1650.

${ }^{18}$ A particular study was made of Cheshunt, Herts, which has good registers and other parish records covering the period $1538-1800$.
} 
Nurse-children were infrequently described as base born and those who were given that description had a named parent(s), often of London. For example, at the Hertford Quarter Sessions of January 1634, there was "A complaint by the inhabitants of Great Hadham, that about three years since one Katherine, a bastard child of one Rose Downes, of Fogwell Court, in the parish of St Sepulchres, London, and of which Thomas Elliott, late of St Faiths, London, Mercer, is the reputed father, was by the said Elliott or some of the parishioners of St Sepulchres, by his procurement, put to nurse to John Barfoote and Joan, his wife, who are both dead, leaving not only the said bastard child, but also five small children of their own, who have all been maintained by the said parish, and that although they have tried they cannot 'find out' the said Elliott." An order was made that the child be sent to the churchwardens and overseers of St Sepulchre's to be provided for. ${ }^{19}$

Bastards of well-to-do people and the orphans and foundlings of London parishes were not the only children sent out to nurse. The majority were the legitimate children of respectable and usually wealthy parents. In some instances, these parents died whilst the child was at nurse, so that once the child was weaned he was returned to his own parish. An order was passed at the 1686 Hertford Quarter Sessions that "Elizabeth and Mary Mannering, daughters of Richard Mannering, Gentleman, deceased, who were formerly put to nurse with Ann Clarke of Great Amwell, widow, be removed to St Georges Southwarke, Co. Surrey, their late fathers last place of settlement". ${ }^{20}$ And in 1677 , an order "concerning the settlement of Mary Drowne, daughter of Robert Drowne, late of Ratcliffe in the parish of Stepney, Co. Middlesex, Mariner, and Mary his wife, both deceased, who was put to nurse with James Haughton of Hartingfordbury, by her uncle John Bluckman, of Whitechapell, Co. Middlesex, Silk Weaver. Afterwards she was sent by an order to the hamlet of Ratcliffe, where the court considered she should be settled."21

These orders give some typical occupations of those who put their infants out to be nursed: mercer, gentleman, mariner, and silk-weaver. A previous study found that members of the aristocracy, the gentry, wealthy merchants, wealthy farmers, scholars, lawyers, physicians, and some clergymen regularly employed wet-nurses. ${ }^{22}$ Those registers used in the present study which state the occupations of either the nurse-child's father or the wet-nurse's husband show that the findings derived from parish registers and other parish records concur with those from other sources. The occupations of fathers of nurse-children derived from eleven parishes in Hertfordshire between 1580 and $1800^{23}$ were: clerk to an earl; gentleman (2); mariner (2); merchant taylor; mercer; silk-weaver. Twenty-four were given the title "Mr"; two the suffix "Esquire"; two were described as "Citizen of London", and one as "Noble".

${ }^{19}$ Le Hardy (1928), op. cit., note 12 above, p. 195.

${ }^{20}$ Le Hardy (1930), op. cit., note 12 above, p. 399.

21 Ibid., p. 304.

22 Fildes, thesis, pp. 149-162.

${ }^{23}$ Aldenham, Cheshunt, Elstree, Flamstead, Much Hadham, Much Hormead, Hunsdon, King's Langley, St Albans, St Stephen's, Sandridge, Totteridge; Le Hardy (1930), op. cit., note 12 above, p. 304. 


\section{Valerie Fildes}

Fathers' occupations between 1580 and 1800 derived from twelve parishes in other counties $^{24}$ were: baker; butcher (3); coachman (2); coachmaster; cutler; embroiderer; fleming (probably a weaver); gentleman (2); glover; grocer; gunstock-maker; haberdasher (3); knight and ambassador; inn-keeper; joiner; labourer; pedlar; sailor; servant; taylor (2); victualler; vintner. Modes of address included: $\mathrm{Mr}$ (19); Sir; Colonel; Esquire (2) and "Citizen of London" (2).

Discovering the occupations of the nurse or her husband proved more difficult, although parish clerks did record occupations during some years in fifteen of the parishes studied. In six Hertfordshire parishes between 1560 and $1750^{25}$ these included: blacksmith (2); bricklayer (2); carpenter; coachman to an earl; cobbler; cowleech; farrier; inn-keeper (or employee at an inn); labourer (6); locksmith; man keeping many servants (2); miller (2); physician; servant to an earl; taylor (2); weaver (2). Eight were addressed as $\mathrm{Mr}$ and one as Doctor. One nurse was addressed as Mistress and one as Nurse; and one was a midwife. Several husbands held positions in the parish including: churchwarden (2); clerk of the parish; parish constable (2); overseer of the poor (2); sexton. After 1750, occupations were rarely given; three were described as labourers, and one was a carter employed by a gentleman.

Outside Hertfordshire, nine parishes listed the occupations or mode of address of the nurse or her husband. ${ }^{26}$ Between 1570 and 1750 , these were: blacksmith; brewer; brickmaker; carpenter; clerk; cooper; cordwainer; gardener (2); glover; joiner; labourer (6); man keeping many servants; miller (3); musician; saddler; shoemaker; shovelmaker (3); taylor (3); thatcher; tiler; trenchermaker; turner (3); waterman (4); weaver (2). Three husbands were addressed as $\mathrm{Mr}$, and one was a churchwarden. Two nurses were addressed as Nurse and one as Mrs. One was formerly a servant. After 1750 , only one indication of status was given: the nurse's husband was addressed as Mr.

Franklyn Dulley, in his study of Aldenham and Elstree, two Hertfordshire parishes that took in large numbers of nurse-children from 1595 to 1750 , found that homes taking in nurse-children ranged from those of the gentry to those of widows unable to pay the poor rates. ${ }^{27}$ Unfortunately, he made no discrimination between the types of nurse-children taken in. In 1669, Stephen Tothill conducted a survey of the householders in the east Hertfordshire parish of Cheshunt, in which he listed the owners and inhabitants of all the property in the parish. ${ }^{28}$ This shows that the families who took in nurse-children in the 1660s and 1670s occupied property and often surrounding land, described as orchards, gardens, or for farming, to which they

\footnotetext{
${ }^{24}$ Compton-cum-Shefford and Toddington, Beds; Chesham, Bucks; Lee, Lewisham, and Orpington, Kent; Kensington, Middlesex; Merstham, Morden, Putney, Stoke D'Abernon, and Wandsworth, Surrey. Forbes, op. cit., note 14 above, p. 195; Cox, op. cit., note 14 above, p. 68; Winters, op. cit., note 14 above, p. 74; Waters, op. cit., note 14 above, p. 66.

${ }^{25}$ Cheshunt, Elstree, Much Hadham, King's Langley, St Albans, St Peter's, Totteridge.

${ }^{26}$ Compton-cum-Shefford and Dunstable, Beds; Chesham, Bucks; Lewisham, Kent; Kensington, Middlesex; Morden, Putney, Wimbledon and Wandsworth, Surrey. Forbes, op. cit., note 14 above, p. 195; Winters, op. cit., note 14 above, p. 82; Cox, op. cit., note 14 above, P. 69.

${ }^{27}$ Franklyn Dulley, 'Nurse-children: a forgotten cottage industry', Hertfordshire Countryside, 1982, 37(274): 14-15.

${ }^{28}$ Stephen Tothill, 'A survey of the parish of Cheshunt', 1669, typewritten copy, transcribed and indexed by Peter E. Rooke, 1958, HRO R.076555.
} 
held the leasehold, copyhold, or (rarely) the freehold. Thus, young children taken in by Cheshunt wet-nurses were unlikely to have been confined in a small room in a country hovel. Probably (and this is borne out by the childhood memories of London foundlings in the eighteenth century $)^{29}$ they spent a certain amount, if not most, of their infancy in fresh country air together with their foster-brothers and -sisters. The finding about parental occupations in parish records largely confirm the findings elicited from literary and medical sources.

Wet-nursing of well-to-do infants tended to be undertaken by women whose husbands had occupations which would involve travel to, or trade links with, both neighbouring parishes and London. To date, nothing has been found to indicate any intermediary between parents and nurse, as was the case in France. ${ }^{30}$ Relatives and friends might recommend a reliable woman of whom they had knowledge, ${ }^{31}$ and some parents sent successive children to the same wet-nurse, ${ }^{32}$ but how and by whom the child was transported from London to parishes up to forty miles away is largely conjecture. Occasional references to such a journey appear in personal papers. For example, in June 1647, the gentlewoman Lady Mary Verney described in some detail, in a letter to her steward, her arrangements for transporting her three week-old son, Ralph, from London to the family home in Claydon, Buckinghamshire, via St Albans in Hertfordshire. In this case, the nurse had obviously travelled to London either in preparation for, or soon after, the birth.

\begin{abstract}
Upon Tuesday next I intend to send my child to St Allbanes [by coach] the nurse is most extreamely desirous to be att home, so if you can posseble I would have you there one Tuesday night and go to Tringe on Wednesday. The nurse sayeth her husband hath a very easy-going horse, and she thinks itt will be best for him to carry the child before him upon pillows, becaus she cannott ride between toe panniers and hold the child. When you come there you will quickly find which will be the best way to carry itt; pray provide for both wayes, and bring a foot man to goe by itt. If her husband doth carry the child, she cannott ride behind him, soe you must provide a horse for her; my sister Mary goes downe with them, so you must bring up a pillion to carry her downe behind you .... pray doe see that they take a great care of the child, and that they goe very softly, for the weather is very hott; if he carries the child before him itt must be tied about him with a garter, and truly I think itt will be a very good way, for the child will nott endure to be long out of ones armes. ${ }^{33}$
\end{abstract}

A reference to weaned infants returning home appears in the church records of the late sixteenth century in the Essex parish of Farnham which adjoins north-east Hertfordshire. In this case, a man pleaded that he had been absent from church because he had "carried children nursed to London and he heard service at Aldersgate church" in London. ${ }^{34}$ This may indicate that he had delivered the children to parents or to officials in the parish of Aldersgate. It seems reasonable to assume that there were links

\footnotetext{
${ }^{29}$ McClure, op. cit., note 1 above, pp. 130-136.

${ }^{30}$ The meneur was an important part of the wet-nursing business in France. See T. G. H. Drake, 'The wet nurse in France in the eighteenth century', Bull. Hist. Med., 1940, 8: 934-948; Sussman, op. cit., note 1 above.

${ }^{31}$ Dorothy Gardiner (editor), The Oxinden letters 1607-1642, London, Constable, 1933, letter from Robert Bargrave to his sister, 14 March 1635.

${ }^{32}$ For example, the eighteenth-century physician, Hans Sloane; discussed in Fildes, thesis, p. 185.

${ }^{33}$ Francis Parthenope Verney and Margaret E. Verney, Memoirs of the Verney family during the seventeenth century, London, Longmans, Green, 2nd ed., 1904, pp. 361-362. I am indebted to the late Dr D. McLaren for providing this reference.

${ }^{34}$ Emmison, op. cit., note 14 above, p. 88.
} 
(based on the trade of London parents or of the wet-nurse's family) between London parishes and particular country parishes. A search for such an association in burial registers revealed that some parishes took several children from a particular London parish, but as parish clerks did not always name the parish of origin but merely stated that the nurse-child was from London, the association between parish of origin and the receiving parish was less well documented than was the transfer of bastards, orphans, and foundlings. Of the last group both the child's name and the London parish were occasionally recorded. For example, in North Mimms, Hertfordshire, in July 1713: "James a nurse-child laid in St Alphage Parish London". In other entries, the connection can be deduced either from the written statements in the register that a child was a foundling or poor child from a named parish, or from the name of the nurse-child. Unnamed foundlings were commonly baptized with the surname of the parish in which they were abandoned, ${ }^{35}$ as in Much Hadham, Hertfordshire, in January 1664: "Thomas Staneing a nurs childe of the parish of Saint Mary Staneing in London"; or in Cheshunt, Hertfordshire, in April 1679; "Thomas Bowe of Bow-Parish in London nursed at George Cocks". London parish officials clearly sent their infants to be nursed in particular country parishes where wet-nursing was a trade undertaken by many women (in the 1650s, at least thirty-seven different families in Cheshunt took in nurse-children). Often, these children were sent to particular families in certain periods, most of whom also nursed wealthier London infants, although occasionally a household took in large numbers of London parish children only (for example, George Cocks of Cheshunt [see above] who buried twenty-one nurse-children between 1672 and 1680. Those who were named bore surnames of London parishes.)

Some country parishes had links with the same London parish over a long period of time; others appear to have taken parish nurse-children from several different areas of London during a comparatively short timespan. Cheshunt accepted children from St Benet's in the 1580s and 1590s; from St Peter's, Allhallows and Shoreditch, between 1600 and 1620; from St Gregory's in the 1640s; and from St Mary's, St Dunstan in the West, and St Christophers's during the 1650s and 1660s. In the forty years following 1670 , Cheshunt women accepted nurse-children from a variety of parishes including St Clement Dane, St Mary le Bow, St Helen's Bishopsgate, St Peter's, St Mary Aldermanbury, Allhallows, and St Lawrence Jewry. Where the specific parish is not named, the area from which the child came is often given. In Cheshunt, these included Coleman Street, Cornhill and Aldgate. In contrast. Much Hadham nursed children from St Benet Sherehog in the 1620s, St Mary Staining in the 1660s, and St Peter's and the area of Hatton Garden in the 1670s. Although exact identification of the parish is not always possible since, for example, several London parishes bear the name St Mary's or St Benet's, it does limit the possible parishes from which nurse-children came and thus allow a search to be made for the baptisms of these children in London registers at a later date, to confirm their parish of origin. ${ }^{36}$

By whatever means these parish infants were transported, their death rate was apparently greater than that of other nurse-children in the same years. It is not uncommon to see the burials of several such infants on the same, or successive, days.

${ }^{35}$ Cox, op. cit., note 14 above, p. 63.

${ }^{36}$ Research in progress indicates that it is possible to trace some London infants to their parishes of origin. 


\section{The English wet-nurse and her role in infant care 1538-1800}

This implies that these children were more susceptible to changes in temperature and environment as well as to infections because their health was initially poorer than that of other nurse-children; or that some infants died in transit and were buried either as soon as they arrived in the receiving country parish, or in the parish where they died. This would explain the burials described as "a nurse child" with no name, no place of origin, and no name of the wet-nurse, although these details were given for other nurse-children buried in the same period. In Cheshunt, which recorded the greatest number of poor/parish infants yet discovered, they only comprised 8-9 per cent of all nurse-child burials - the great majority during the later seventeenth and earlyeighteenth centuries. So, from the study of parish records to date, it is clearly wrong to assume that the hundreds of nurse-children buried in country parishes were either bastards or the parish poor of London.

Wet-nursing in some parishes was a significant female occupation that some women pursued for many years after their own childbearing had ceased. A young mother might wet-nurse for a short time either while suckling a child of her own or if her own infant died. It was also a trade for young widows who made a living initially from wet-nursing and later by taking in slightly older children to dry-nurse. ${ }^{37}$ Where sufficient detail allows a study of the baptisms and burials of the wet-nurses' own children, a similar picture emerges to that found by McLaren in Chesham, Buckinghamshire, between 1578 and $1601 ; 38$ women tended to have from three to five infants (most of whom survived infancy) and then began taking children to wet-nurse. ${ }^{39}$ Although certain individuals appear only to have taken parish poor or only the infants from wealthy families, a woman supporting herself or adding to the family income by wet-nursing would clearly nurse those children that were available at the time. Payment was higher for the privately-employed nurse particularly in the eighteenth century, ${ }^{40}$ so that women must have preferred this association but, if she had weaned her nurse-child and returned it to the parents, she would need to find another infant to suckle fairly quickly in order to maintain her milk supply. Parish infants from London were apparently in constant supply (at least in the lateseventeenth and early-eighteenth centuries) ${ }^{41}$ and were a means for a woman to keep up her supply of breast-milk and consequently her contribution to the family income. In addition, for a short period during the sixteenth century, wet-nurses had the opportunity to suckle infants from Christ's Hospital in London (founded 1552), which in its early years sent out infants mainly to Hertfordshire and Essex parishes, although some were nursed within London and others as far away as Great Yarmouth in Norfolk (135 miles distant). ${ }^{42}$ Women who buried nurse-children from the hospital also took in infants to nurse from parents or from London parishes. Although some

\footnotetext{
${ }^{37}$ This was also noted by Dully, op. cit., note 27 above, p. 15.

${ }^{38}$ McLaren, op. cit., note 3 above.

${ }^{39} \mathrm{See}$, for example, the Hadhams in the late-sixteenth and early-seventeenth centuries.

${ }^{40}$ Fildes, thesis, pp. 158-162; Dorothy Marshall, The English poor in the eighteenth century, New York, Augustus Kelly, 1969, pp. 99-101; Ivy Pinchbeck and Margaret Hewitt, Children in English society, vol. 1: From Tudor times to the eighteenth century, London, Routledge \& Kegan Paul, 1969, pp. 173-177.

41 This is inferred from the numbers that were buried in Hertfordshire during this period.

42 By the late-sixteenth century, fewer suckling infants were accepted by the hospital, and by June 1624, the only children accepted under four years of age were children of Freemen of London and born within the city. By 1640 , no children under three years were accepted, and the charity became an educational institution only. Pearce, op. cit., note 12 above, pp. 19-42; personal communication from Dr Violet Rowe, 1983.
} 
Valerie Fildes
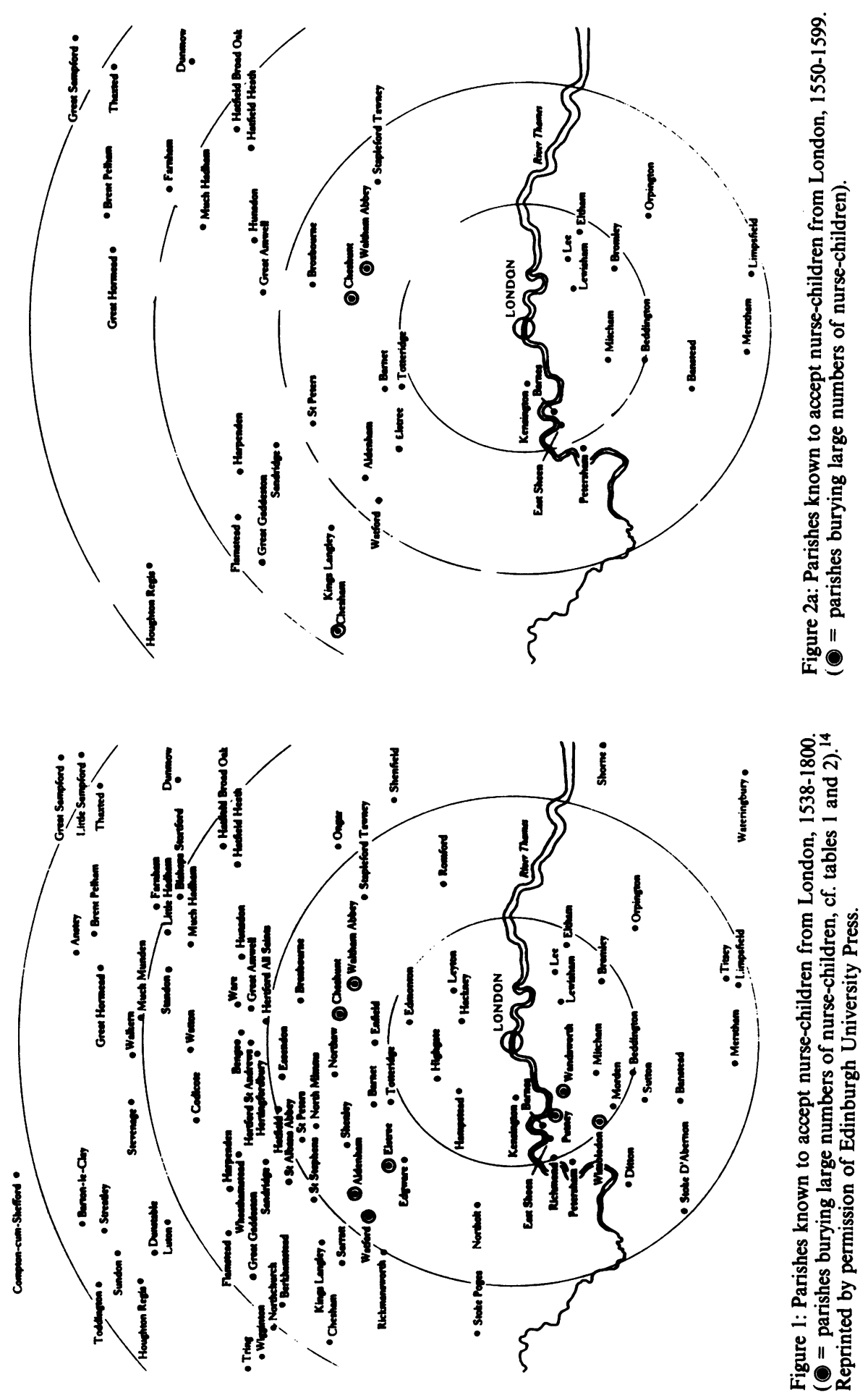
The English wet-nurse and her role in infant care 1538-1800
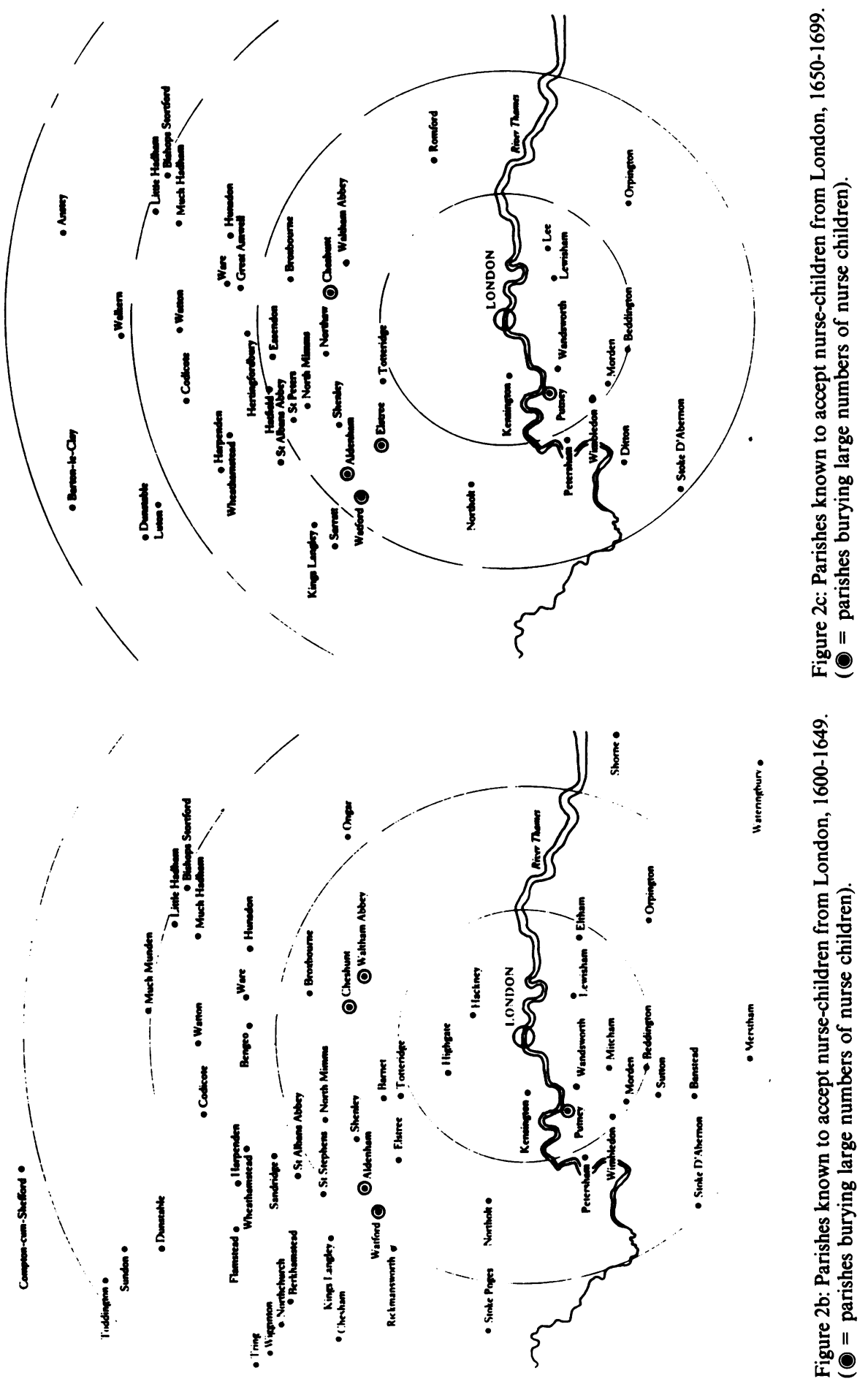


\section{Valerie Fildes}
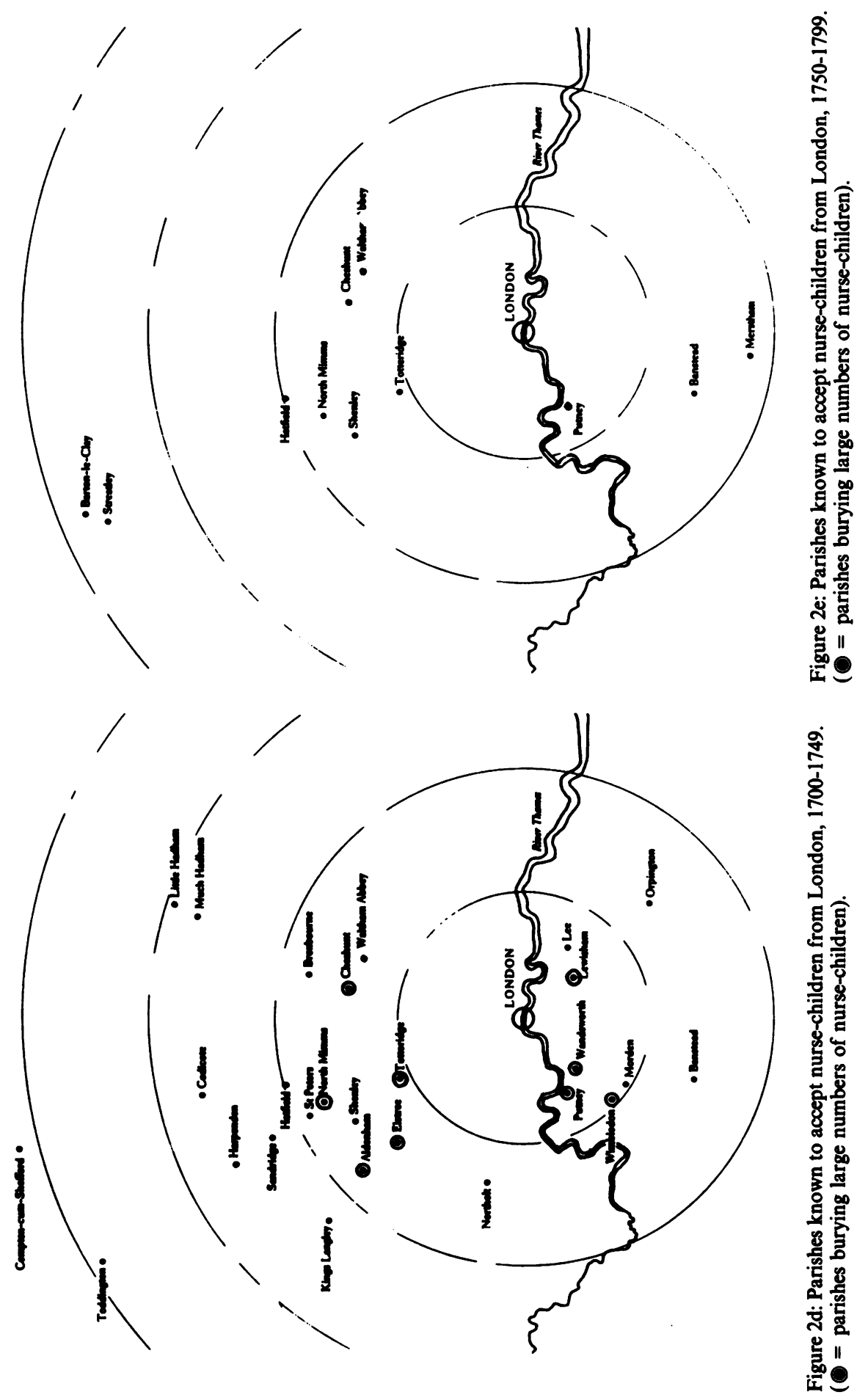
The English wet-nurse and her role in infant care 1538-1800

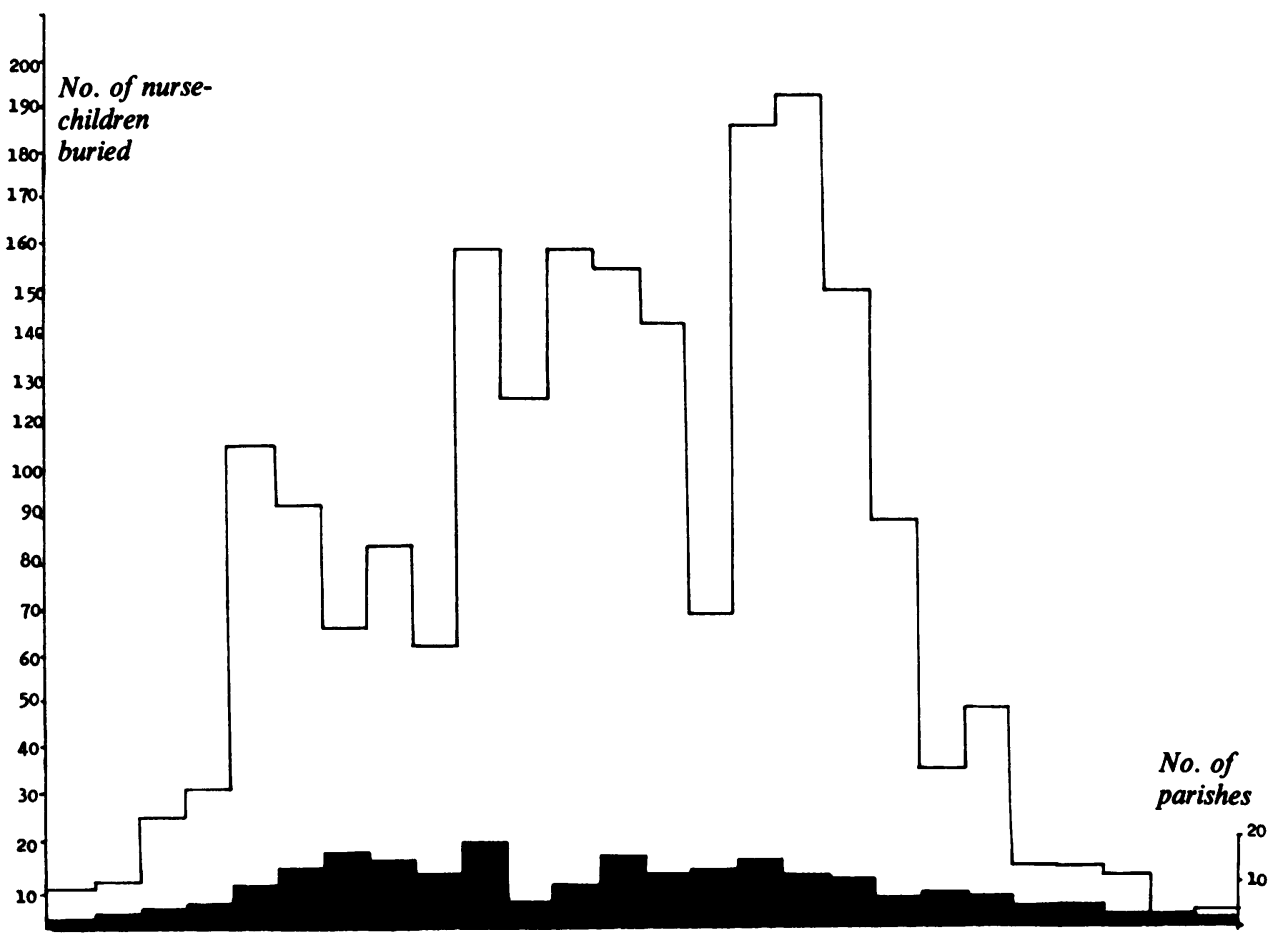

Figure 3a: Distribution of 1912 burials of nurse-children in 36 Hertfordshire parishes 1540-1800

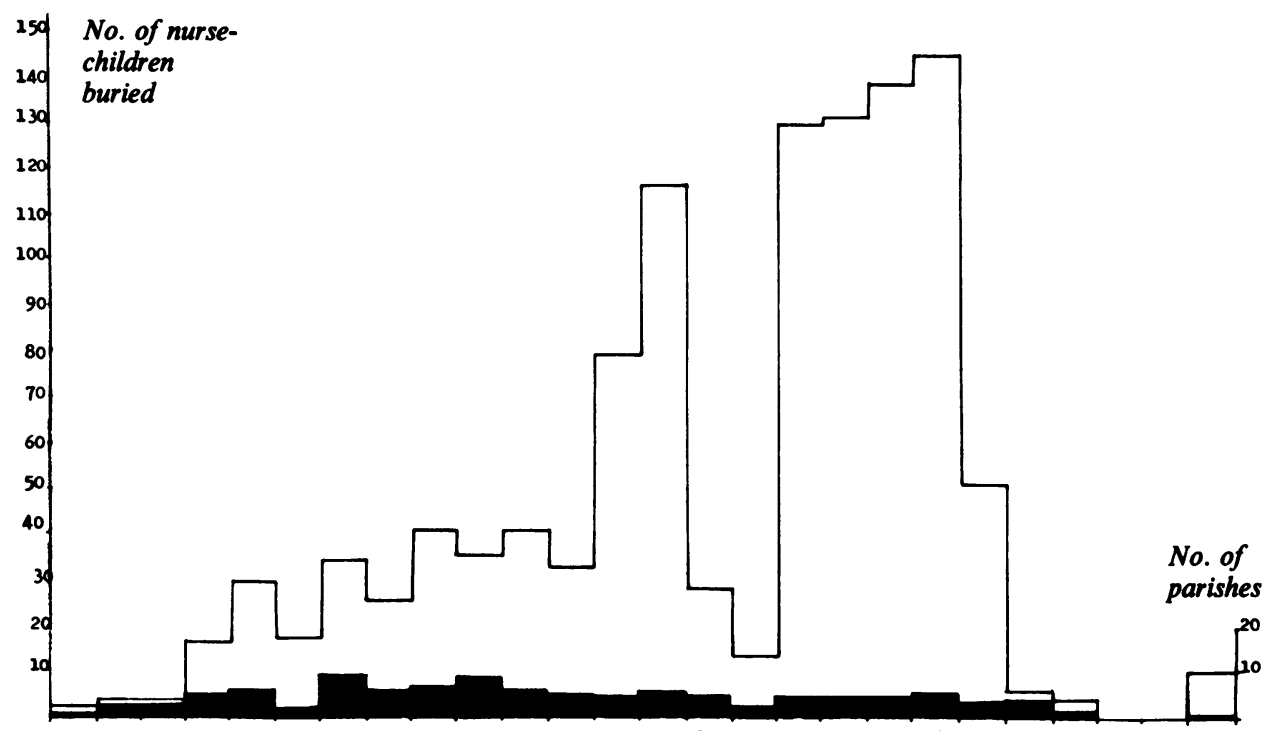

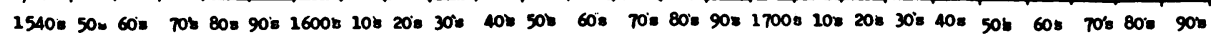
Ten-year periods

Distribution of 1148 burials of nurse-children in 25 parishes around London (excluding Hertfordshire) 1540-1800. 


\section{Valerie Fildes}

nurse-children were stated to be from neighbouring parishes, this was relatively unusual; where their origin was given, nurse-children usually came from London or from parishes many miles distant.

In order to take in infants from so far away, receive payment, and return them when they were weaned, women had to live close to a major route to London. It is therefore not surprising that parishes which lined major roads, especially coaching routes, buried the largest numbers of nurse-children. Hertfordshire was traversed by many roads from London including Watling Street to the north-west, Ickneild Street, Ermine Street and the Great North Road. Apart from one minor road in the north-east of the county, major routes in the period 1538-1800 were identical to those of today. ${ }^{43}$ This study to date shows that the most likely place to find a "wet nursing parish" is along major roads leading up to fifty miles from London, ${ }^{44}$ and particularly those near coaching inns where overnight stops and a change of horses were provided. Examples in Hertfordshire include St Albans (used by Lady Verney in 1647) and Waltham Cross in the parish of Cheshunt. However, when the distribution of "wet-nursing parishes" is examined over a long period it is clear that the incidence and extent of wet-nursing did not depend solely upon highways.

Figure 3b: Histogram showing the distribution of 3060 burials of nursechildren in 61 parishes around London 1540-1800.

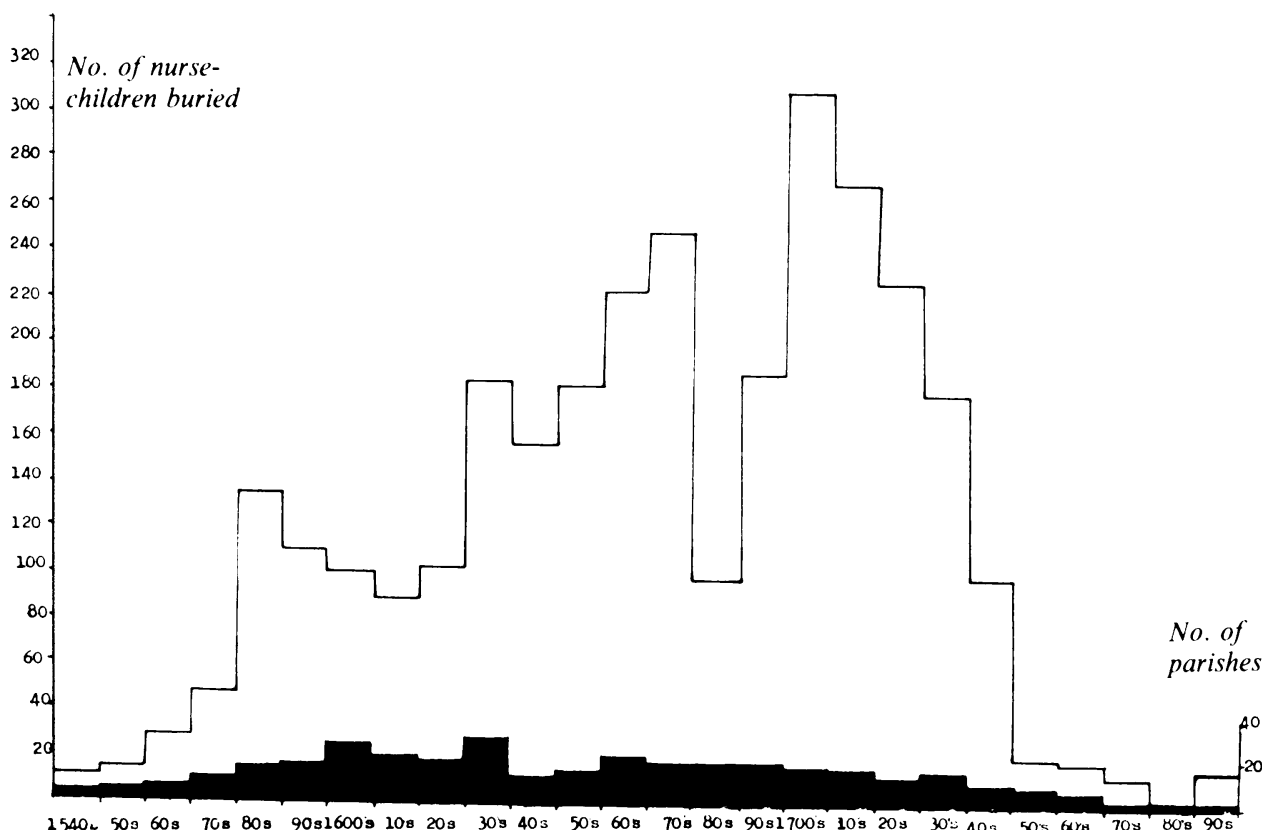

Ten-year periods

43 I am grateful to the staff of the Hertfordshire Record Office for providing this information. See also $H R O$ county maps no. 15, drawn by Robert Morden, c. 1695, the earliest map to show roads.

${ }^{44}$ For example, parishes close to Watling Street (now the A5) included Elstree and Aldenham, which buried large numbers of nurse-children. The route north from London (now the A10) was lined by Cheshunt, Herts, and Waltham Abbey, Essex, two parishes with exceptionally large numbers of nurse-child burials. 


\section{The English wet-nurse and her role in infant care 1538-1800}

Figure 1 shows the accepting parishes over the period 1538-1800 but if this map is drawn for fifty-year periods beginning in 1550 , then a clearer pattern emerges (see fig. 2). First, the number of parishes varies considerably, with the greatest number in the period 1600-49. This may be partly due to better records although, in Hertfordshire in particular, records of the 1640s are frequently missing. Second, an area in north-west Hertfordshire which was close to a highway from London is not represented in any period. Third, relatively few parishes were taking in nurse-children over the whole time-span. For example, those to the west and north-west of London which took comparatively large numbers from 1550 to 1649 no longer feature in the laterseventeenth and eighteenth centuries. The fourth, and most interesting, point is that by the second half of the eighteenth century only five of the Hertfordshire parishes and six from other counties were still burying nurse-children. Not only did the number of parishes decrease, but so did the numbers of nurse-children. Sixty-six per cent of the 3,060 nurse children were buried between 1650 and 1749 whilst after 1750 this declined to less than three per cent. Examination of ten-year periods shows that the sharp decline in nurse-child burials began in the 1730s in Hertfordshire, in the 1740s outside Hertfordshire, and the combined figures demonstrate a steady decline from 1710 (see fig. 3). (It should be noted that, although these histograms demonstrate that larger numbers of London nurse-children were buried in the country in the late-seventeenth and early-eighteenth centuries, this does not mean that the practice of wet nursing was necessarily increasing. It is equally likely that it was related to the increase of London's population during this period, or to the absolute numbers of infants abandoned by their parents increasing. Research in progress indicates that in many London parishes there was a large and relatively sudden increase in the number of foundlings baptized and then sent out to country nurses between $c .1680$ and $c .1720$.)

In fact, the four findings given above are inter-related and connected with events in the local history of Hertfordshire and its close neighbours, and to events in the capital.

If, as this study has attempted to show, wet-nursing was a "cottage industry" in both Hertfordshire (see fig. 4) and the other home counties, ${ }^{45}$ then its distribution and survival in particular periods would depend upon which other home-based industries in the area could be pursued by women in order to supplement or supply the family income. (This disregards for the present the undoubted contraceptive advantage of continued frequent breast-feeding, which was a probable additional motive for wet-nursing. $)^{46}$ In the period under investigation, Hertfordshire, and the parts of Bedfordshire and Buckinghamshire which adjoined it to the north and the west, had two lucrative cottage industries with which wet-nursing had to compete. The first and most important was the straw-plaiting trade, which was established during the seventeenth century in the south-east midlands, and centred on north-west Hertfordshire around the large market town of Hitchin and the nearby Bedfordshire towns of Luton and Dunstable. Ultimately, the latter became the main centres for the manufacture of straw hats in the eighteenth century and particularly the nineteenth

\footnotetext{
45 Researchers who have made any study of wet-nursing have suggested either directly or by inference that it occurred on the scale of a cottage industry. For example, Finlay, op. cit., note 2 above; McLaren, op. cit., note 3 above; Dulley, op. cit., note 27 above.

${ }^{46}$ Discussed in detail in Fildes, thesis, pp. 89-92; McLaren, op. cit., note 3 above.
} 
Valerie Fildes

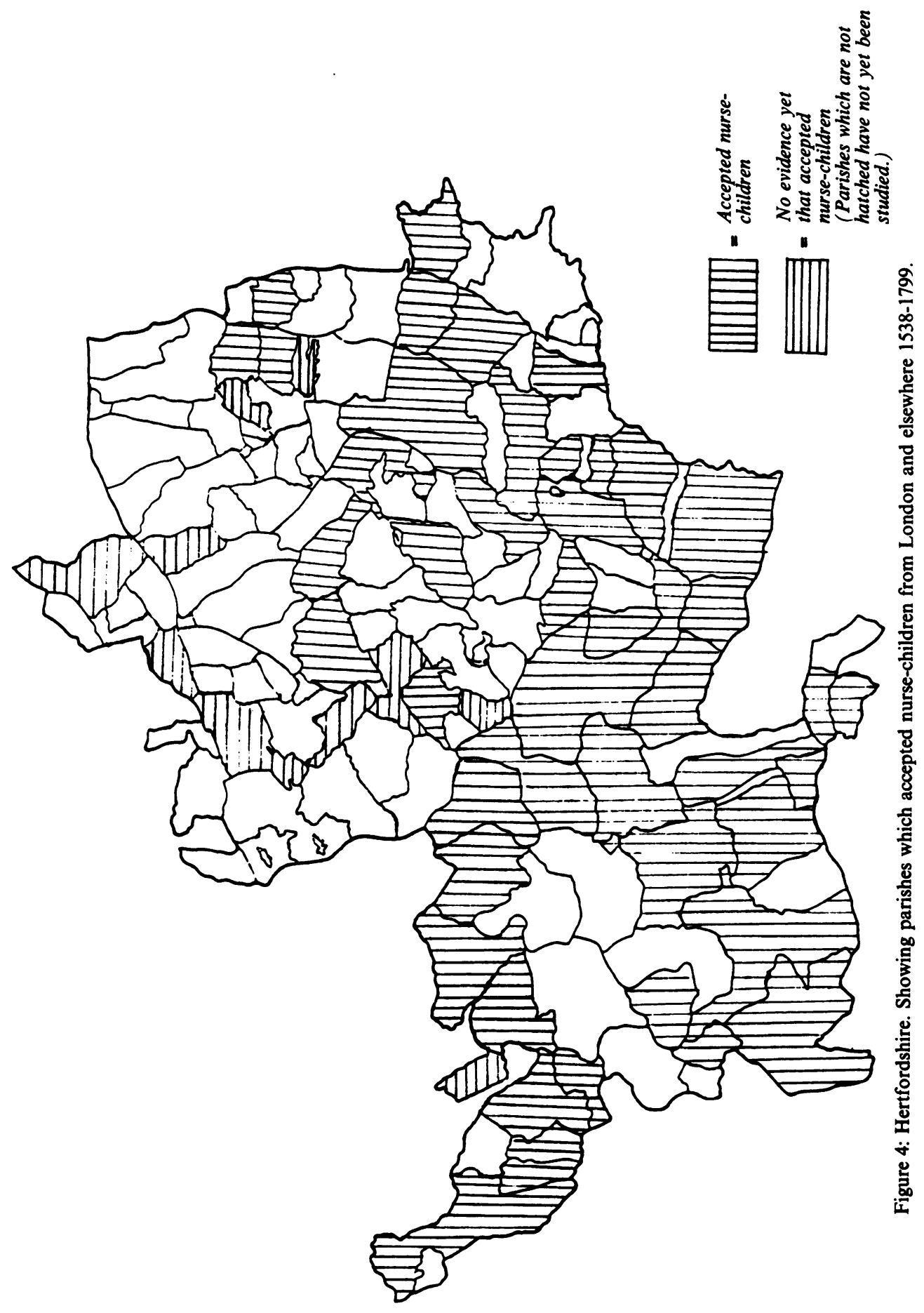




\section{Valerie Fildes}

century. Straw-plaiting was extremely well paid. At its height, women and young girls could earn in a day a sum equal to a man's wages for a week working on the land. Although wet-nurses could earn substantial amounts, particularly if they took in several children, straw-plaiting, also home-based but not involving the trouble and physical problems of breast-feeding, presented an attractive alternative. By the late-eighteenth/early-nineteenth century, it had spread to cover most of the western half of Hertfordshire. ${ }^{47}$

The second industry, based mainly in Bedfordshire and Buckinghamshire, was lace-making. Beginning in the area in the late-sixteenth century, it spread during the seventeenth and eighteenth centuries to cover a large area of the south-east midlands. Some western parishes of Hertfordshire, such as Tring, were involved although it could not compete with the more remunerative straw-plaiting in the north-west of the county. However, lace-making paid sufficiently well to make it a cottage industry of some significance in the seventeenth and eighteenth centuries. ${ }^{48}$ These home-based crafts explain both the absence so far of any evidence of wet-nursing in north-west Hertfordshire, particularly in the Hitchin area, and the shift in incidence and extent of wet-nursing from the western half of the county in the sixteenth and seventeenth centuries to a few parishes in the central southern area by the late-eighteenth century. An additional minor factor may have been the well-established tradition of Nonconformity in Hertfordshire, where most communities had a chapel, and often an associated burial ground, by the eighteenth century. Methodism, arising in the 1730s, similarly endorsed the teachings of all dissenting religions from the time of the Reformation by denouncing wet-nursing and urging mothers to feed their own children. $^{49}$

Other events of significance to rural wet-nursing occurred in London. The workhouse system of the eighteenth century meant that London parishes, which formerly sent their young children out to nurse, instead employed workhouse inmates to suckle or, more usually, to dry-nurse young infants abandoned in the parish or born within the workhouse. The high death rates of such children have been copiously related elsewhere. And these were recorded in the mid- and late-eighteenth century at exactly the time that nurse-child burials in the countryside were declining. ${ }^{50}$ Also of importance was the founding of two charities in the early eighteenth century: the lying-in wards and hospitals in 1747-50; and the London Foundling Hospital in 1739. The former provided places for respectable poor women to have the attendance of (male or female) midwives at their confinements, and additionally provided centres within the capital where respectable women could be obtained at short notice by wealthy families seeking wet-nurses. ${ }^{51}$ The latter meant that infants who formerly

\footnotetext{
${ }^{47}$ N. Agar, Hitchin's strawplait industry, Hitchin Historical Society and North Hertfordshire District Council Museum Service, [n.d.], pp. 3-4; Charles Freeman, Luton and the hat industry, Luton Museum and Art Gallery, 1953, pp. 7-17; Jean Davis, Straw plait, Aylesbury, Bucks, Shire Publications, 1981, pp. 3-6.

${ }_{48}$ Charles Freeman, Pillow lace in the east midlands, Luton Museum and Art Gallery, 1958, pp. 9-21.

49 Cheshunt was a centre for Nonconformists in the seventeenth century and had a flourishing chapel by 1700. Jack Edwards, Cheshunt in Hertfordshire, Cheshunt Urban District Council, 1974, pp. 72-73; also Fildes, thesis, p. 146.

S0 Ibid., pp. 298-306.

51 Jean Donnison, Midwives and medical men. A history of interprofessional rivalries and women's rights, London, Heinemann, 1977, pp. 25-27; Fildes, thesis, p. 156.
} 


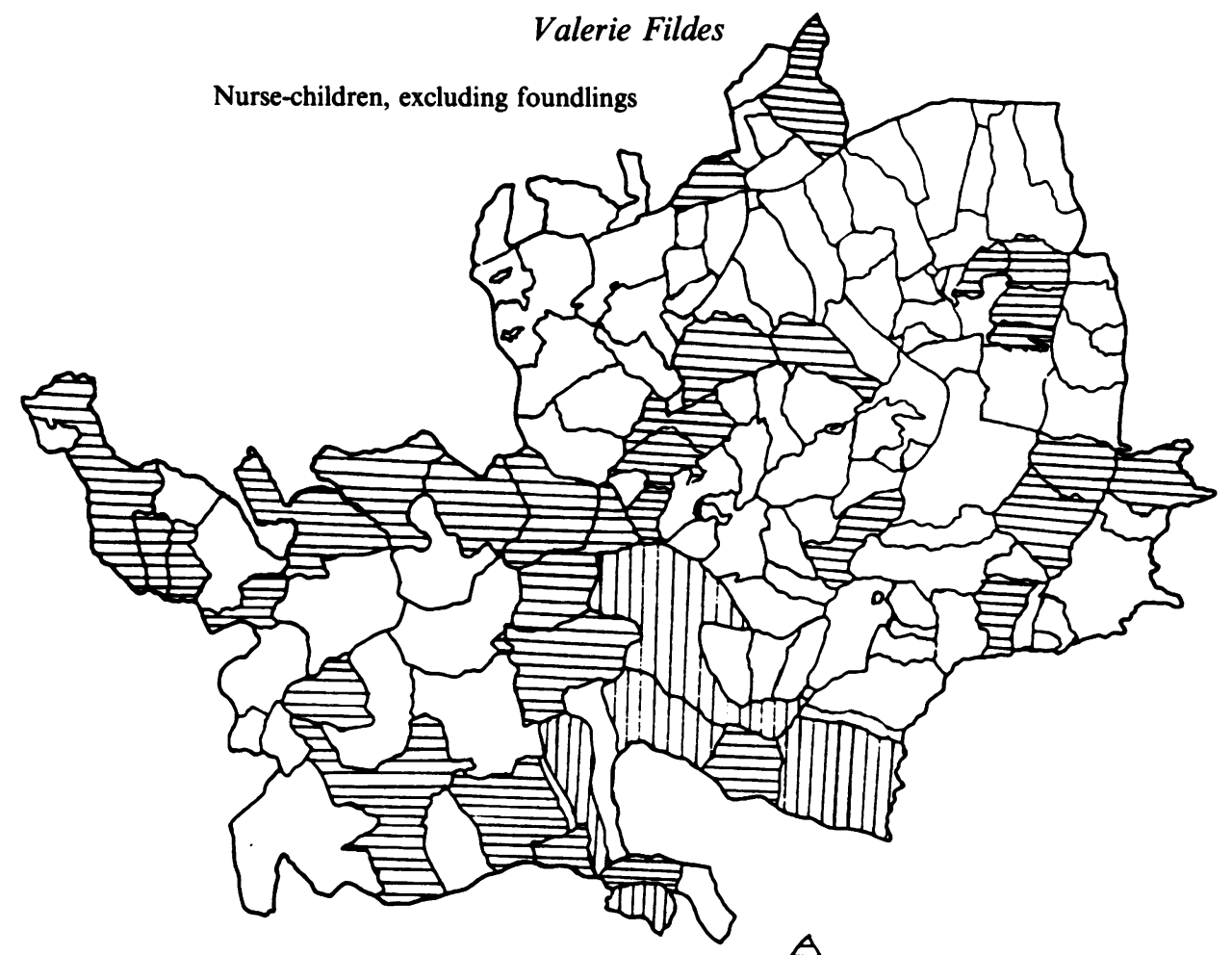

Children from the Foundling Hospital

Children from the Foundling Hospital

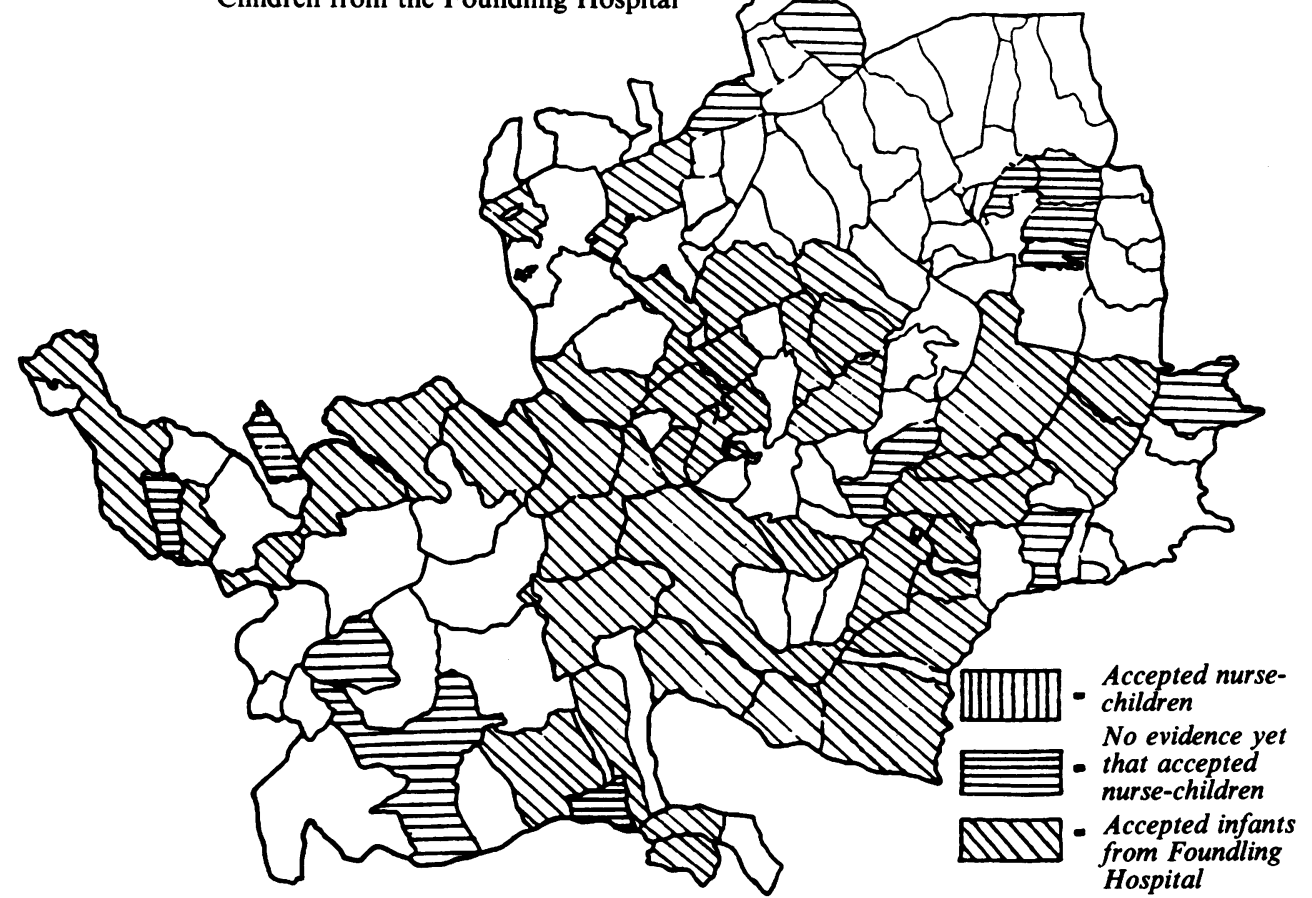

Figure 5: Hertfordshire parishes which accepted nurse-children from London and elsewhere 1750-1799. 
would have been abandoned were taken into an establishment committed to raising as many as possible to maturity. At first, only small numbers of infants were put out to nurse, and burials of nurse-children from the Foundling Hospital appear sporadically in parish registers. But, during the period of "general admission" 1756-60, large numbers of foundlings were buried both in Hertfordshire and in other parishes around London. The health of foundlings in this four-year period was much poorer, some arriving at the hospital either dead or near to death; but the majority were sent out to be nursed in the country, by wet-nurses if they were able to suck, otherwise by dry-nurses. ${ }^{52}$

The presence of such large numbers of foundling nurse-children in Hertfordshire parishes in the 1750 s and early 1760 s provided the opportunity to verify the suggestion that the Foundling Hospital took advantage of wet-nursing links already in existence. As can be seen in figure 5, there is no evidence to support this theory. Numbers of foundlings were buried in parishes where no nurse-children had previously been mentioned, and no foundlings were buried in a few parishes where wet-nursing formerly had been a flourishing occupation for over two centuries. In fact, as has been shown by historians of the Foundling Hospital, ${ }^{53}$ the hospital wet-nurses were chosen by local inspectors who were men and women of some rank and education in their districts. The parishes that took in large numbers of foundlings were those in an area surrounding the residence of an inspector and, unlike the preceding two centuries, were not necessarily close to a major highway from London. Although, following a 1767 Act of Parliament, parish officials in the London area had to send their orphans, bastards, and foundlings to the Foundling Hospital and pay the governors for their care, there was overall a smallerintake of foundlings after $1760 .{ }^{54}$ As before 1756 , children from the hospitalagain appear sporadically in the burial registers of country parishes. The governors had decided early on that women who lost two children at nurse would not be allowed to take in any more foundlings; ${ }^{55}$ it was therefore to the advantage of the nurses to keep their nurse-children out of the burial registers. It should not be overlooked, of course, that one reason for nurse-children disappearing from burial records for either short or long periods was that the wet-nurses were more successful in rearing them; possibly related to factors such as infants having a more robust constitution initially, the presence or absence of major epidemics, and (after the great improvement of roads during the eighteenth century) a much shorter journey from home to the place of nursing. ${ }^{56}$

Another logical assumption is that fewer infants were sent out to nurse in the eighteenth century, not only by parish officials but by parents. No evidence has been found to suggest that more parents were taking wet-nurses into their homes rather than sending infants out to the countryside (as was the case in eighteenth-century

\footnotetext{
52 McClure, op. cit., note 1 above, pp. 101-105; Lloyd Hart, op. cit., note 1 above; An account of the hospital for the maintenance and education of exposed and deserted young children, London, Foundling Hospital, 1749.

${ }_{53}$ Arthur Jones, 'The Foundling Hospital and its arrangements for country nursing 1756-67', unpublished dissertation for extension diploma in history, University of London, 1978.

${ }^{54} \mathrm{McClure}$, op. cit., note 1 above, pp. 137-148.

55 Jones, op. cit., note 53 above; Adrian Wilson, personal communication.

${ }^{56}$ Travelling in a coach-and-four from the City of London to Ware, Herts, took approximately four hours in the mid-eighteenth century. Pearce, op. cit., note 12 above, p. 167.
} 


\section{Valerie Fildes}

Hamburg) ${ }^{57}$ However, it did become fashionable during the mid- and late-eighteenth century for the wealthy either to raise their infants by hand, employing a dry-nurse in the home, or for mothers themselves to breast-feed. ${ }^{58}$ How much this was related to the virtual absence of nurse-children from the parishes studied is difficult to determine, given the statement by the surgeon Thomas Mantell in 1787 that more infants died in the parishes near large towns because of "the numbers being continually sent to be nursed in the adjacent country" ${ }^{59}$ It is possible that parents preferred to send their infants to parishes much closer to London to facilitate more frequent visiting than was the custom in the sixteenth and seventeenth centuries.$^{60}$ It is an unexpected finding of this study that (when travelling conditions, especially in winter, were more difficult) sixteenth- and seventeenth-century children appear to have been nursed farther away from the capital than infants in the eighteenth century. However, confirmation of this point requires further work on parishes closer to London than those of Hertfordshire.

When estimating the extent of wet-nursing in particular periods (as adjudged solely by nurse-child burials) several factors must be considered, in particular: (a) epidemic disease and the health of parents both in London and in the receiving country parishes; (b) infant mortality and, especially, maternal mortality in London and the receiving parishes; (c) poor harvests, high food prices, and the possibility of scarcity or famine in the country parishes. The chief epidemic diseases recorded by parish clerks were bubonic plague and smallpox. In the case of plague, nurse-children, or the person who transported them from town to country, could be responsible for transmitting the disease. This can be suspected particularly when, in a given year (such as 1609 in Beddington, Surrey) only the nurse-child and the members of the household to which it was sent died from plague, the remainder of the parish apparently remaining unaffected. An outbreak of plague in a small parish could sometimes wipe out families who took in London nurse-children. For example, in Much Hadham in 1603 two families among several who accepted London nurse-children, the Goodsonns and the Sagars (who were related by marriage), their households, and a nurse-child from each, died from plague. This effectively ended for thirty years a parish wet-nursing business which had thrived since at least 1567 . Such an incident suggests that either the transporting or placing system was carried out by members of these families or their servants, or that when London parents heard of an epidemic in a particular parish they sent their infants elsewhere to avoid the infection. Similarly, a major plague year in London may have made unaffected country parishes reluctant to accept infants from the capital.

It has been suggested that bubonic plague may preferentially affect women in the latter stages of pregnancy and particularly those in childbed, their infants being largely

\footnotetext{
${ }^{57}$ Mary Lindemann, 'Love for hire: the regulation of the wet nursing business in eighteenth-century Hamburg', J. Family History, 1981, 6: 379-395.

${ }^{58}$ Fildes, thesis, pp. 87-89, 310; Trumbach, op. cit., note 6 above, ch. 5; Valerie Fildes, 'Changes in infant feeding practices and ideas from 1600 to 1800 with particular reference to those affecting infant mortality and maternal-infant bonding', in Wolfgang Eckart and Johanna Geyer-Kordesch (editors), Heilberufe und Kranke im 17. und 18. Jahrhundert, die Quellen- und Forschungssituation, Munster, Münstersche Beiträge zur Geschichte und Theorie der Medizin, no. 18, 1982, pp. 174-200.

59 Thomas Mantell, Short directions for the management of infants, London, 1787, p. xiv.

${ }^{60}$ Fildes, thesis, p. 158.
} 
stillborn or undelivered; ${ }^{61}$ and that it tends to infect adults to a greater extent than children. ${ }^{62}$ It could be expected, therefore, that despite an increase in stillbirths following a plague year in London, at the same time so many infants and children would be orphaned that a greater number would be placed with country nurses; and possibly this greater number would be visible by an increase in the number of nurse-children buried in country parishes. (One factor of note is that, where a parish records large numbers of deaths from plague, the number of nurse-children recorded is frequently small, fewer than in the years preceding and immediately following a plague year.) An epidemic of plague in a country parish would similarly cause a high mortality of childbearing women (for example Cheshunt in 1665), and thus reduce the number of women available for hire as wet-nurses. Thus the parish would be likely to show a reduction or absence of nurse-child burials immediately following such an outbreak. (Cheshunt buried only two nurse-children-two per cent of all burials-in 1666, compared with 6-14 per cent in the preceding four years).

Smallpox, especially in the seventeenth and early-eighteenth centuries, was principally a disease of childhood. It most affected children above the age of infancy, young infants at the breast being less susceptible. ${ }^{63}$ Those who survived an attack during childhood were consequently immune in later life; hence the occasional insistence that wet-nurses should not be employed unless they had survived the disease. ${ }^{64}$ As with plague, smallpox epidemics recorded in country parishes do not include unduly large numbers of nurse-child burials attributed to the disease. For example, an examination of the four decades showing the largest numbers of nurse-child burials in the parish of Cheshunt (1580s; 1630s; 1640s; 1650s) shows that, even in years when plague and smallpox were recorded as major causes of death, nurse-children were rarely stated to be victims of these diseases.

The general state of health of both mothers and their babies affected the chances of survival of infants sent out to nurse. A small, sickly infant was less likely to survive a long journey soon after birth than one who was born normally and at term to a healthy, well-nourished mother. ${ }^{65}$ This factor was especially relevant with foundlings and those whose mothers had died (possibly unattended) in childbirth. Many foundlings were abandoned well-clothed and apparently well-fed (according to the records of Christ's Hospital in the sixteenth century and the London Foundling Hospital in the eighteenth century), but others were so ill-nourished and ill-clothed that they barely survived their baptism. ${ }^{66}$ Recent research has shown that maternal mortality in England from 1600 to 1800 , although not as high as has been generally assumed, was particularly high in the second half of the seventeenth century (22.8 per cent higher than in the period $1600-49)$ and that during the eighteenth century, increasingly more mothers survived

61 J. F. D. Shrewsbury, A history of bubonic plague in the British Isles, Cambridge University Press, 1971, pp. 539-540.

62 Ibid., p. 316.

${ }^{63}$ George Frederic Still, The history of paediatrics. The progress and study of diseases of children up to the end of the XVIIIth century, Oxford University Press, 1931, p. 324.

${ }^{64}$ See Fildes, thesis, p. 191;'Lectures anatomical and chirurgical' by William Hunter, Wellcome Institute for the History of Medicine, MS 2966, 1775; Alexander Hamilton, $A$ treatise on the management of female complaints and of children in early infancy, Edinburgh, 1792, p. 548.

${ }^{65}$ Discussed in Fildes, thesis, p. 293-294.

${ }^{66}$ Cox, op. cit., note 14 above, pp. 63-67. 


\section{Valerie Fildes}

childbirth and the puerperium (see table 3). ${ }^{67} \mathrm{~A}$ similar pattern has been shown to occur in infant mortality, which was particularly high in the 1680s and then fell steadily during the eighteenth century. ${ }^{68}$ Relating these facts to nurse-child burials produced an unexpected result. At a time when both infant and maternal mortality were at their height in the late-seventeenth century, there was a considerable reduction in the number of nurse-child burials in country parishes. It might be expected that, if more London mothers were dying in childbirth whilst their infants survived, more infants would be sent out to country parishes and consequently more would be visible in the burial registers. ${ }^{69}$ Alternatively, if infant mortality was also high, fewer infants would be sent out to nurse.

\section{TABLE 3: MATERNAL MORTALITY IN A GROUP OF ENGLISH PARISHES 1600-1800* AND THE PERCENTAGE CHANGE 1600-49-1750-99}

$\begin{array}{ccc}\text { Years } & \begin{array}{c}\text { Maternal mortality } \\ \text { (per 1000 live births) }\end{array} & \begin{array}{c}\text { Percentage } \\ \text { change }\end{array} \\ 1600-49 & 15.3 & \\ 1650-99 & 18.8 & +22.8 \\ 1700-49 & 13.6 & -27.7 \\ 1750-99 & 8.8 & -35.3\end{array}$

* These corrected figures showing maternal mortality in a group of English parishes were supplied by Dr R. Schofield of the Cambridge Group for the History of Population and Social Structure.

If maternal mortality was high in the wet-nursing parishes, there would be fewer women available to take in nurse-children, whilst if there was a high infant mortality unassociated with maternal deaths, then more women would be available to accept infants to nurse. It is difficult to obtain figures for the exact mortality of women but, using the very crude index of women described as "wife of" or "widow", then in the parishes studied no excessive mortality of women has been noted other than in epidemics of plague, particularly in 1665 . It is possible that, if children were dying soon after birth, women who wished for further children were reluctant to wet-nurse since they would be less likely to conceive while breast-feeding. ${ }^{70}$

The decline in nurse-child burials in the 1680s was not caused by a decrease in the number of parishes taking in nurse-children (a scatter diagram shows no correlation in any period between the number of nurse-children buried and the number of parishes in which they were nursed). Until a larger sample is examined for this period it would be unwise to state categorically that there was a decline in wet-nursing in the 1680 s, or that wet-nurses were more successful in rearing foster-children during this decade. One possibility should be considered, however; this was a decade during which experiments in raising infants by hand rather than by breast-feeding became noticeable. ${ }^{71}$ If infants

\footnotetext{
${ }^{67}$ I am grateful to Dr. R. Schofield for this information.

68 Valerie Fildes, 'Neonatal feeding practices and infant mortality during the eighteenth century', J. biosocial Sci., 1980, 12: 313-324.

${ }^{69}$ According to contemporary sources such as the Bills of Mortality, half of the infants born alive did not survive until their second birthday; therefore it is assumed that nurse-child burials represent approximately fifty per cent of those placed with nurses in the parish. A substantial increase in nurse-children living in the parish could be expected to result in an associated increase in nurse-child burials.

70 Fildes, thesis, pp. 89-92; McLaren, op. cit., note 3 above.

${ }^{71}$ Fildes, op. cit., note 58 above, pp. 185-195.
} 


\section{The English wet-nurse and her role in infant care 1538-1800}

were either remaining in their homes or being sent out to be dry-nursed, then (given the evidence from this investigation) it is unlikely that such infants would be recorded as nurse-children. It has been suggested elsewhere that the comparatively high mortality of infants among the British aristocracy was related to experiments with infant feeding methods. ${ }^{72}$ The preliminary results from this study tend to support this hypothesis. If further examination of parish records shows a consistent fall in nurse-child burials during this decade, this would suggest that experimental feeding practices were not confined to the aristocracy.

The part played by poor harvests, high food prices, scarcity and possibly famine in the country parishes should not be neglected. If prices were high, then women would be motivated to take in nurse-children in order to buy food and other necessities. At the same time, if a wet-nurse were poorly nourished, she may well have had an inadequate supply of breast-milk for one or more infants, and have been more inclined to supplement the nurse-child's diet by handfeeding with pap or gruel at an early age. In turn, this would put the infant at greater risk of contracting gastro-intestinal infections as well as marasmus. Thus, in years of dearth, a greater mortality of nurse-children might be expected. Similarly, in years of good harvests and lower food prices, where the wet-nurse was well nourished and less desperate to take in infants in order to feed her family, a lower mortality among nurse-children could be expected. Years of scarcity occurred in the $1580 \mathrm{~s}, 1590 \mathrm{~s}, 1620 \mathrm{~s}, 1630 \mathrm{~s}, 1670 \mathrm{~s}$, and $1680 \mathrm{~s} .{ }^{73} \mathrm{In}$ four of these decades the number of nurse-child burials was relatively high $(1580$ s, $1590 \mathrm{~s}, 1630 \mathrm{~s}, 1670 \mathrm{~s}$ ), and also in the 1690s in Hertfordshire parishes when grain prices at Hertford and Ware (recorded in Little Hormead parish register) were very high for several years. Although this suggests a link between high prices, scarcity, and nurse-child burials, the factor of poor nourishment of the wet-nurse or her nurse-child was so closely related to resistance to disease in general, to sporadic outbreaks of plague, and to other epidemic diseases, that no causal link should be made without closer study of the parishes concerned.

A preliminary examination was made of the months during which nurse-children were buried in the decades showing the highest mortality in particular parishes. In theory, if large numbers of nurse-children were consistently buried in July, August, and September, this would indicate that infants were dying from gastro-intestinal diseases (linked with the degree of cleanliness of food and feeding utensils, and thus with partial or complete dry-nursing) ${ }^{74}$ whilst if greater numbers were buried in the winter months, particularly January to March, then this would suggest acute respiratory ailments (in addition to a colder environment and attendant hypothermia) as a major cause of death. Local epidemics of the childhood diseases of measles, whooping-cough, and scarlatina could kill large numbers of infants and children in most months of the year, and thus influence the percentage mortality in a particular year. In addition, seasonal distribution of births in London would affect the numbers of infants put out to nurse in particular seasons. However, four parishes with large

\footnotetext{
${ }^{72}$ Ibid, pp. 185-195; Fildes, op. cit., note 68 above, pp. 318-319.

73 J. M. Stratton and Jack Houghton Brown, Agricultural records AD 220-1977, London, John Baker, 1978, pp. 37-94.

${ }^{74}$ Discussed in Fildes, thesis, pp. 315-319.
} 
numbers of nurse-child burials in certain periods were examined to calculate the percentage of burials in each quarter of the year (see table 4).

\section{TABLE 4: THE MONTHS OF THE YEAR IN WHICH NURSE-CHILDREN WERE BURIED IN FOUR PARISHES AROUND LONDON}

$1580-1719$

\begin{tabular}{|c|c|c|c|c|c|c|c|}
\hline \multirow[t]{2}{*}{ Parish } & \multirow[t]{2}{*}{ Years } & \multirow{2}{*}{$\begin{array}{c}\text { No. of } \\
\text { nurse- } \\
\text { children } \\
\text { buried }\end{array}$} & \multicolumn{4}{|c|}{$\begin{array}{c}\text { Percentage of burials in } \\
\text { each quarter }\end{array}$} & \multirow{2}{*}{$\begin{array}{c}\text { Highest no } \\
\text { of burials } \\
\text { (month) }\end{array}$} \\
\hline & & & Jan-Mar & Apr-Jun & $\begin{array}{l}\text { July- } \\
\text { Sept }\end{array}$ & Oct-Dec & \\
\hline Cheshunt, Herts & $1580-99$ & 104 & 27 & 24 & 27 & 22 & March \\
\hline Cheshunt, Herts & $1630-59$ & 227 & 29 & 22 & 24 & 25 & March \\
\hline $\begin{array}{l}\text { Putney, Surrey } \\
\text { Aldenham \& }\end{array}$ & $1660-79$ & 150 & 22 & 31 & 31 & 16 & August \\
\hline Elstree, Herts & $1690-1719$ & 283 & 24 & 30 & 27 & 19 & May \\
\hline Putney, Surrey & $1700-19$ & 177 & 24 & 28 & 27 & 21 & April \\
\hline
\end{tabular}

N.B. Aldenham and Elstree are considered together for the purposes of this table; they were adjoining parishes showing similar trends, especially during the period 1690-1720.

At this stage, no firm conclusions can be drawn other than that, in the months October, November, and December, burials were consistently low compared with the other months of the year. Before 1660, the majority of nurse-children died in the January to March and July to September quarters; after that date, more died in the April to June and July to September quarters, but there were no noticeable trends either in individual parishes or in particular decades, that would allow a dogmatic statement that most nurse-children died from either winter respiratory ailments or from summer gastro-intestinal problems. The latter is rather unexpected in view of medical comments about infant deaths. For example, in his De morbis acutis infantum of 1689 , the physician Walter Harris stated that "From the middle of July to about the middle of September, the Epidemical Gripes of children are so rife every year, that more of them usually die in one month, than in three or four at any other time: For the heat of the season commonly weakens them at least, if it does not entirely exhaust their strength."

An attempt was made to investigate whether there was a differential mortality between male and female infants by plotting the sex of the 703 nurse-children who were buried in Cheshunt, but the large number of children of unidentified sex (239) made this of academic interest only; especially as the number of each sex originally sent out to nurse in the parish is unknown and it is not certain that the sex ratio of infants sent out to nurse was necessarily normal.

\section{CONCLUSIONS}

Despite the limitations of using parish registers, which are sometimes incomplete or missing, an investigation of the identity and social position of both English wet-nurses and the infants they nurtured provides results that confirm the findings of an earlier study in which both medical and literary sources were used. The findings from one county alone do not differ markedly from those in a random group of parishes from other counties, thus research into the remaining parishes of Hertfordshire is desirable 
and may be taken as representative of the custom and business of wet-nursing in the London area during the period 1538 to 1800 .

Parishes that buried very large numbers of nurse-children should not be excluded from any investigation as being unrepresentative (as was Waltham Holy Cross in Finlay's work), since this study has shown that certain parishes did take many more nurse-children than others, whilst some buried none at all. It is probable that in some areas wet-nursing was, by tradition, a regular, thriving, and lucrative occupation, which compared favourably with other available work for women. Particularly in the sixteenth and seventeenth centuries, it was practised on such a scale that it can be classed as a cottage industry. Since a significant number of London infants (both the wealthy and the poor) were nourished and nurtured by these country women, any discussion of infant and child care must include the important role of surrogate mother which was played by wet-nurses during the impressionable years of early infancy.

\section{ACKNOWLEDGEMENTS}

I am grateful to the Wellcome Trust and the Nestle Company Ltd for financing this study. This research was initiated and stimulated by the work and encouragement of Dr Roger Finlay and, particularly, the late Dr Dorothy McLaren, who discussed possible areas of research and provided many references. It would have been impossible to undertake this study without the interest and advice of the County Archivist and his staff at the Hertfordshire County Record Office (HRO), Hertford; the staff of the Local Studies Library, Hertford, and the British Library, London. I am also indebted to the Cambridge Group for the History of Population and Social Structure for allowing me access to their records and providing information about maternal mortality.

\section{RECORDS OF THE HERTFORDSHIRE PARISHES}

ALDENHAM

William Brigg (editor), The parish registers of Aldenham, Hertfordshire 1559-1659, St Albans, [privately printed], 1902, pp. 103-165.

William Brigg (editor), The parish registers of Aldenham, Co. Herts, 1660-1812, St Albans, [privately printed], 1910, pp. 58-245.

ANSTEY

Abstract of Anstey parish registers, typed transcript in HRO, L3014, 3 vols., 1540-1837.

ASHWELL

Ashwell parish registers. Transcribed from the originals in the Hertfordshire Record Office, Ashwell, Field Studies Centre, HRO, L2943, [n.d.].

AYOT ST PETER

Manuscript transcript of the Bishop's transcripts 1609-1812, HRO, no number, [n.d.].

CHIPPING BARNET

Bishop's transcripts for Chipping Barnet 1563-1795, HRO, no number, [n.d.].

Manuscript transcript of Parish Registers of Chipping Barnet 1569-1692, HRO, no number, [n.d.].

EAST BARNET

Bishop's transcripts for East Barnet 1582-1792, HRO, no number, [n.d.].

Manuscript transcript of East Barnet parish register 1582-1692, HRO, no number, [n.d.].

BENGEO

Manuscript transcript of the Bishop's transcripts 1606-1812, HRO, no number, [n.d.].

BERKHAMSTEAD

Manuscript transcript of Bishop's transcripts 1606-69, HRO, no number, [n.d.].

LITTLE BERKHAMSTEAD

Manuscript transcript of Bishop's transcripts 1609-80, HRO, no number, [n.d.]. 


\section{Valerie Fildes}

BISHOPS STORTFORD

Bishops Stortford parish registers, HRO D/P211/1-4.

Manuscript transcript from the registers of Bishops Stortford, 1561-1626, HRO, no number, [n.d.].

BUSHEY

Manuscript transcript of Bishop's transcripts 1581-1690, HRO, no number, [n.d.].

CALDECOTE

Manuscript transcript of Bishop's transcripts 1609-1812, HRO, no number, [n.d.].

CHESHUNT

The parish registers of Cheshunt 1559-1800, HRO D/P291/1-17.

Overseers' accounts for Cheshunt Street ward 1729, HRO D/P2912/3-5.

Vestry minutes for the parish of Cheshunt 1731-51, HRO D/P29 8/1.

Overseers' accounts for Cheshunt Street ward 1689, HRO D/P 12/3.

Overseers' accounts for Waltham Cross ward 1724-1813, HRO D/P12/17-21.

Constables' accounts 1668, HRO D/P29 9/1.

CODICOTE

Manuscript transcript of Codicote parish registers 1558-1867, HRO, no number, [n.d.].

ELSTREE

A. R. T. Eales, The first register book of the parish church of Elstree 1655-1757, [n.p.], 1914, pp. 29-69.

Bishop's transcripts for Elstree 1585-1800, HRO, no number.

Parish registers of Elstree 1758-1812, HRO D/P36 1/1-2.

FLAMSTEAD

F. M. Barrell (transcriber), Transcripts of Flamstead parish registers, vol. 1: 1548-1781, vol. 2: 1782-1838, HRO, no number, 1972.

GREAT GADDESDEN

Manuscript transcripts of Great Gaddesden, Hertfordshire, parish registers 1558-1840, vol. 2: burials, HRO, no number, [n.d.].

LITTLE GADDESDEN

Manuscript transcripts of the Bishop's transcripts 1609-1812, HRO, no number, [n.d.].

LITTLE HADHAM

William Minet (transcriber and editor), Registers of the parish of Little Hadham in Hertfordshire 1559 to 1812, [n.p.], 1907.

Little Hadham parish registers, HRO D/P43 1/1-3.

Copy of court roll, HRO 42068, 28 March 1706, and 42069, 21 April 1715.

MUCH HADHAM

Manuscript transcript of Much Hadham parish registers 1559-1811, HRO, no number, [n.d.].

HARPENDEN

Manuscript transcript of the parish registers of Harpenden, Co. Herts. 1562-1812, HRO, no number, [n.d.].

HATFIELD

Bishop's transcripts for Hatfield, 1604-1812, HRO, no number, [n.d.].

William Brigg (copied a transcript by Wilton Hall), The parish registers of Hatfield, Co. Herts, HRO, no number, 1894.

HEXTON

Manuscript transcript of the Bishop's transcripts 1581-1696, HRO, no number, [n.d.].

HITCHIN

Manuscript transcript of the Bishop's transcripts 1609-99, HRO, no number, [n.d.].

GREAT HORMEAD

Hertfordshire parish registers. Much Hormead 1538-1900, HRO, L2953, [n.d.].

LITTLE HORMEAD

Herbert C. Andrews (transcriber), The parish registers of Little Hormead, Herts, 1588-1916, London, Society of Genealogists, [n.d.], HRO 2952. 
HUNSDON

Herbert Cokayne Gibbs, The parish registers of Hunsdon, Co. Hertford 1546-1837, London, St Catherine's Press, 1915, pp. 65-87, 135-139, 155-167, 216-238.

KNEBWORTH

Frank A. Richardson (transcriber), Knebworth parish registers 1596-1837, HRO L2699 204/125C, 1971.

ABBOTS LANGLEY

Manuscript transcript of the Bishop's transcripts 1570-1696, HRO, no number, [n.d.].

KINGS LANGLEY

Mary Tisdall (transcriber), Transcripts of Kings Langley parish registers, vol. 1: 1558-1812, HRO, no number, 1979.

LAYSTON WITH BUNTINGFORD

Abstract of Layston parish registers 1563-1837, 6 vols., HRO, L2463 204/125E, [n.d.].

LILLEY

Manuscript transcript of the Bishop's transcripts 1609-1713, HRO, no number, [n.d.].

NORTH MIMMS

North Mimms parish register. HRO D/P691/1-3; D/P69 1/12.

Bishop's transcripts for North Mimms 1604-1812, HRO, no number, [n.d.].

NEWNHAM

Manuscript transcript of the Bishop's transcripts 1581-1696, HRO, no number, [n.d.].

NORTHAW

Bishop's transcripts for Northaw, HRO, no number, [n.d.].

Northaw parish register. Transcripts from the Bishop's transcripts, St Albans, Herts., Potters Bar

and District Historical Society, Historical records nos. 3 and 3A, part 1: 1564-1632, part 2: 1681-1713, [n.d.].

Northaw parish registers, HRO D/P731/1-2. These are badly burned and mostly indecipherable. NORTHCHURCH

Manuscript transcripts of the Bishop's transcripts 1606-1810, HRO, no number, [n.d.].

NORTON

Thomas F. Allen, The parish registers of Norton, Hertfordshire. Transcribed from the registers and arranged in alphabetical order, HRO, 1955.

PUTTENHAM

Manuscript transcripts of the bishop's transcripts 1609-1812, HRO, no number, [n.d.].

REDBOURN

Manuscript transcript of the Bishop's transcripts 1581-1696, HRO, no number, [n.d.].

RICKMANSWORTH

Manuscript transcript of the Bishop's transcripts 1569-1695, HRO, no number, [n.d.].

RIDGE

Manuscript transcript of the Bishop's transcripts 1567-1714, HRO, no number, [n.d.].

ST ALBANS ABBEY

William Brigg (transcriber), The parish registers of St Albans Abbey 1558-1689, Harpenden, [n.p.], 1897.

The parish registers of St Albans Abbey 1690-1800, HRO D/P901/2.

The Bishop's transcripts for St Albans Abbey 1570-1755, HRO, no number, [n.d.].

ST ALBANS, ST MICHAEL'S

Manuscript transcript of the Bishop's transcripts 1572-1687, HRO, no number, [n.d.].

ST ALBANS, ST PETER'S

Manuscript transcript of the parish registers of St Peter's (St Albans) 1558-1812, HRO, no number, [n.d.].

ST ALBANS, ST STEPHEN'S

Manuscript transcript of the Bishop's transcripts 1561-1697, HRO, no number, [n.d.].

SANDRIDGE

Transcripts of the parish registers of Sandridge 1559-1840, HRO, L2954, [n.d.]. 


\section{Valerie Fildes}

SARRAT

Manuscript transcript of the Bishop's transcripts 1581-1714, HRO, no number, [n.d.].

SHENLEY

Shenley parish registers, HRO D/P99/1/1-2.

The Bishop's transcripts for Shenley 1604-1813, HRO, no number, [n.d.].

SHEPHALL

Manuscript transcript of the Bishop's transcripts 1581-1697, HRO, no number, [n.d.].

STEVENAGE

E. W. B. Cordingly (transcriber), Transcript of Stevenage parish register. Baptisms, marriages and burials 1653-1726, HRO, 1960.

Stevenage parish registers, HRO D/P1051/1-5.

Manuscript transcript of the Bishop's transcripts for Stevenage, HRO, no number, [n.d.]. TOTTERIDGE

Stanley G. R. Barratt (editor), 'The parish register of Totteridge 1569-1802', in A short history of Totteridge in the county of Hertford, London, Eliot Stock, 1934, pp. 115-145.

TRING

Manuscript transcript of the Bishop's transcripts 1606-1812, HRO, no number, [n.d.].

WALKERN

William Brigg (transcriber), The parish register of Walkern, Co. Herts, 1558-1680, HRO, no number, [n.d.].

Manuscript transcript of the parish register of Walkern. HRO, no number, [n.d.].

WALLINGTON

Wallington register no. 1, 1661-1751, HRO, no number, [n.d.].

WATFORD

The parish register of Watford (St Mary's), HRO D/P1171/1-8.

Manuscript transcript of the Bishop's transcripts for Watford, HRO, no number, [n.d.].

WATTON-AT-STONE

Manuscript transcript of the Bishop's transcripts 1609-99, HRO, no number, [n.d.].

WESTON

Manuscript transcript of the Bishop's transcripts 1606-1758, HRO, no number, [n.d.].

WHEATHAMSTEAD

Thos. F. Allen, The parish registers of Wheathamstead, Herts. 1604-1839 arranged alphabetically, HRO, 1954.

The parish registers of Wheathamstead, HRO D/P1221/1-2.

The Bishop's transcripts for Wheathamstead 1604-1813, HRO, no number, [n.d.].

WIGGINTON

Manuscript transcript of the Bishop's transcripts 1601-1812, HRO, no number, [n.d.].

WYDDIAL

Abstract of Wyddial parish register 1664-1837, 2 vols., HRO L2870 204/125E, [n.d.].

\section{RECORDS OF THE BEDFORDSHIRE PARISHES}

F. G. Emmison (editor), Bedfordshire parish registers, vol. 4: Barton in the Clay, Streatley and Sundon, Bedford, County Record Office, 1932.

F. G. Emmison (editor), Bedfordshire parish registers, vol. 52: Compton-cum-Shefford, Bedford, County Record Office, [n.d.].

F. G. Emmison (editor), Bedfordshire parish registers, Vol. 42: Dunstable 1552-1812, Bedford, County Record Office, 1951.

Parish registers of Houghton Regis 1538-1812, Bedfordshire Parish Register series vol. 65, Bedford, County Record Office, 1981.

Parish Registers of Luton 1602-1754, Bedfordshire Parish Register Series, Vol. 53B, Bedford, County Record Office, 1979.

F. G. Emmison (editor), Bedfordshire parish registers, vol. 23: Toddington, Bedford, County Record Office, 1941. 


\section{RECORDS OF THE BUCKINGHAMSHIRE PARISHES}

J. W. Garrett-Pegge, A transcript of the first volume, 1538-1636, of the parish register of Chesham, in the county of Buckenham, London, Elliot Stock, 1904, pp. 257-347.

E. Lionel Reynolds (transcriber), The register of the parish of Stoke Poges in the county of Buckingham 1563-1653, Bucks Parish Register Society, 1912, pp. 54-74.

\section{RECORDS OF THE ESSEX PARISHES}

The parish registers of Ongar, Essex, [privately printed for F. A. Crisp], 1886.

The parish registers of Stapleford Tawney, Essex, [privately printed for F. A. Crisp], 1892.

\section{RECORDS OF THE KENT PARISHES}

Leland Lewis Duncan and Arthur Oswald Barron (editors), The register of all the marriages, christenings and burials in the church of S. Margaret, Lee, in the county of Kent, from 1579 to 1754 , Lee, Lewisham Antiquarian Society, 1888, pp. 39-54.

Leland Lewis Duncan (editor), The register of marriages, christenings and burials in the church of Saint Mary, Lewisham, Kent (being such portions of the registers as were saved from the fire of 1830) from 1558 to 1750, London, Lewisham Antiquarian Society, 1891, pp. 9-112.

Herbert Charles Kirby (editor), The register of the marriages, christenings and burials in the parish church of All Saints, Orpington, in the county of Kent, from 1560 to 1754, London, Lewisham Antiquarian Society, 1895, pp. 5-64.

\section{RECORDS OF THE MIDDLESEX PARISH}

F. N. MacNamara and A. Story-Maskelyne (editors), The parish registers of Kensington, Co. Middlesex. From A.D. 1539 to A.D. 1675, London, Harleian Society, 1890, pp. 89-146.

\section{RECORDS OF THE SURREY PARISHES}

F. A. Heygate Lambert (editor), The registers of Banstead in the county of Surrey 1547-1789, London, Parish Register Society, 1896, pp. 23-94.

W. Bruce Bannerman (editor), The parish registers of Beddington, Co. Surrey, London, Parish Register Society, 1917, pp. 35-48.

Reginald Illingworth Woodhouse (transcriber), The registers of Merstham, Surrey, 1538-1812, London, Parish Register Society, 1902, pp. 19-122.

F. Clayton (editor), The registers of Morden, Surrey, 1634-1812, London, Parish Register Society, 1901, pp. 3-57.

W. Bruce Bannerman (editor), The parish register of Putney, in the county of Surrey, 3 vol., [privately printed], 1913-1916, pp. 90-459.

W. Bruce Bannerman (editor), The parish registers of Stoke D'Abernon, Co. Surrey, London, Parish Register Society, 1917, pp. 31-39.

W. Bruce Bannerman (editor), The parish registers of Sutton, Co. Surrey, 1636-1837, London, Parish Register Society, 1915, pp. 3-121.

John Traviss Squire (transcriber), The registers of the parish of Wandsworth in the county of Surrey (1603-1787), Lymington, 1889, pp. 284-399.

The parish register of Wimbledon, Co. Surrey, London, Surrey Record Society, 1924, pp. 137-206. 